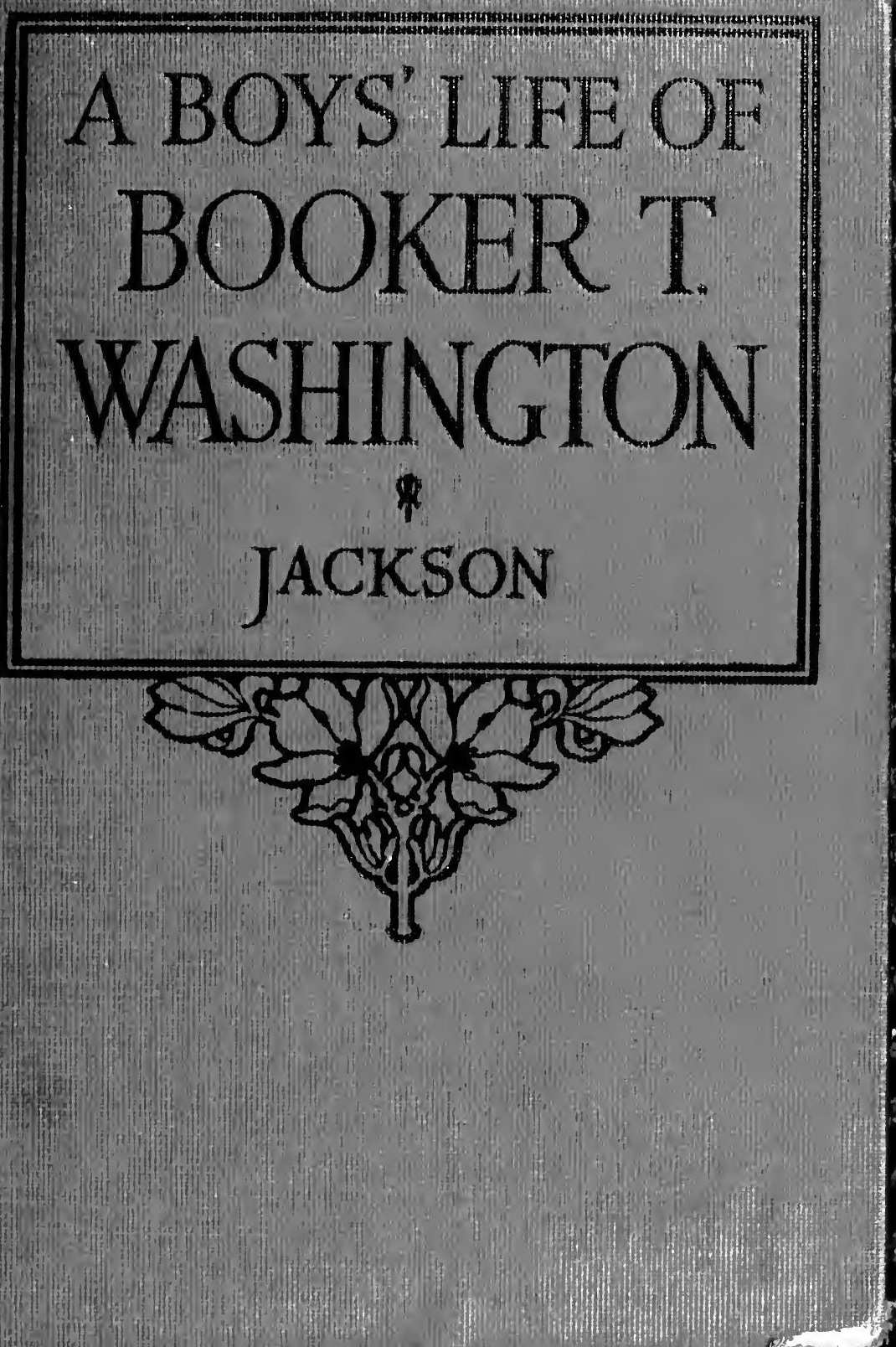


$B W$

\section{Aบ:5536}

IHE CENTRAL CHILDREN'S ROOH DONNELL LIBRARY CENTER

20 WEST 53 STREET

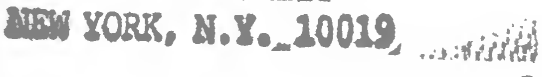




\section{Digitized by the Internet Archive in 2007 with funding from \\ Microsoft Corporation}




\title{
A BOYS' LIFE $\mathrm{OF}$
}

\section{BOOKER.T. WASHINGTON}

\author{
BY \\ W. C. JACKSON
}

Vice President of the North Carolina College for Women, Greensboro, and Professor of History

NEW YORK

THE MACMILLAN COMPANY

1922

All rights reserved 
PRINTED IN THE UNITED STATES OF AMERICA

\section{COPYRIGHT, I922, By THE MACMILLAN COMPANY}

Set up and electrotyped. Published June, 1922

\section{$A 925536$}




\section{PREFACE}

THE single aim in telling the story that follows is to interest boys in the life of Booker T. Washington.

This man's life was of such singular and vital importance in the history of his own race and in the history of our country that it ought to be familiar to all the youth of the land, and to the negro youth especially, since it is the greatest inspiration to the latter to be found in the annals of American history.

There has been no attempt to be original or exhaustive in the treatment. While a great mass of material has been consulted, it should be frankly stated that the stery follows very closely the material found in Washington"s "Up irom Slavery" and "My Larger Edrication," and Scott and Stowe's "Booker T. Wrishingion: Builder of a Civilization."

The author desires to acknowledge his indebtedness to Doubleday, Page and Company for permission to use extensive quotations from these books.

If some boy by reading this book is inspired to higher ambition and encouraged to nobler effort, the author will feel that the book is fully justified. 



\section{FOREWORD}

THIs is the story of Booker T. Washington. It is the story of a boy who was born a slave and who in manhood became the leader of ten million people; who was born in poverty and ignorance and became the greatest orator and teacher of the negro race; who was born of an ignorant and backward race and became the friend of the greatest and best men of all races of all the world.

He was a brave man. He had courage and backbone. He was not afraid. He had courage to fight for what he believed to be the right.

He was an energetic man. There was not a lazy bone in him. No man ever lived a more strenuous life than he did. He loved his work; and few other men ever did so much work in a lifetime.

He was just and fair-minded. He could see right for the white man as well as for the negro. He never intentionally did any one, white or black, an injustice.

He was an honest man; honest in his thinking as well as in his business; honest, frank, and open in his speeches and his writings. He looked facts squarely in the face.

He was a wise man. He had intelligence. He had good judgment. He knew the right thing to do and to say, and he did it and said it. 
He was a modest man. He did not boast or brag. He did not try to get money or office or high position. He was content to do his work as an honest man.

He was a patriotic man. He loved his country and believed this to be the greatest nation in the world; and he was ready to give his life for it if necessary.

He had will power. He made up his mind about things, and, when he had made a decision, he could not be discouraged nor turned aside. He would see his plans through, and he would stand by his convictions to the last.

He had self-control. He did not lose his temper or his tongue. He kept himself in hand. He did not lose his head or waste his time and thought and effort on useless and needless things.

He was a great lover of animals. He loved the pigs and the chickens, the horses and the dogs, the birds and the fishes, and every living thing.

Above all he loved folks. He loved the people of all races. He was a friend not only to the black man but likewise a friend to the red man, the yellow, the brown, and the white.

He loved his race. He was not ashamed of it. He was proud of its history; of its great achievements in the past. He had an abounding confidence in its future. He believed that in the days that lie ahead the negro race is to play a wonderful part.

It is well worth while to know about this man. 


\section{CONTENTS}

CHAPTER

PAGE

I. EARly Childhood . . . • • • • • •

II. Boyhood DAYS • • • • • • • • • • 99

III. Planning for an Education • • • • • I4

IV. School Days at Hampton. . • • • • 22

V. Beginning Life in the Outside World • 33

VI. BACK AT HAMPTON . . . . . . . . 40

VII. Building a Great School • • . • • 45

VIII. Strenuous Days. . . . . . . . . 56

IX. Raising Money for Tuskegee • • • . 67

X. Making Speeches . . . . . • • . 76

XI. Success as Educational Leader. • • . 88

XiI. Leading His People • • • • • • • 105

XIII. Political Experiences • • • • • . II 2

XIV. Visits to Europe . . . . . . . . e il8

XV. Booker T. Washington: The Man . . 229 


\section{LIST OF ILLUSTRATIONS}

PAGE

Symbolic Group Erected at Tuskegee Institute (1922) . . . . . . . . . . . . Frontispiece

Founder's Day Drill at Tuskegee . . . . . 6

Cabinetmaking at Tuskegee . . . . . . . 23

Booker T. Washington as a Hampton Graduate

(I875) . . . . . . . . . . . . . . 24

Booker T. Washington's Class (i875) at Hampton

Institute . . . . . . . . . . . 3 . 3

Tuskegee's First Group of Buildings . . . 5 I

A Sunday Afternoon Band Concert on the Campus 58

Automobile and Buggy Trimming at Tuskegee . . 6 I

Class in Physical Training at Tuskegee . . 65

White Hall; Chapel; Tatum Hall, Tuskegee

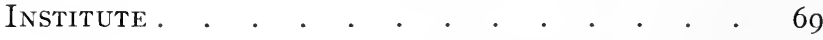

John A. Andrew Memorial Hospital, Tuskegee

Institute. . . . . . . . . . . • • • 72

Class in Photography, Tuskegee Institute • 74 Chemistry Class, Tuskegee Academic DepartMENT • • • . . . . . . . • • • •

Truck Gardening, Tuskegee Institute • • 92 Domestic Science Class at Tuskegee . • • 95 


\section{LIST OF ILLUSTRATIONS}

PAGE

The Students' Band of a Rural School • • • 99 Tailoring Division, Tuskegee Institute • • . io Booker T. Washington, First Principal of TuskeGeE InStitute • • • • • • • • • • • I - I Booker T. Washington and His Family • • . ${ }^{3} 32$ Robert Russa Moton, Successor to Booker T. Washington at Tuskegee . . . . . . . . . Booker T. Washington and His Grandchildren . I4 I 



\section{A BOYS' LIFE OF BOOKER T. WASHINGTON}

\section{CHAPTER I}

\section{EARLY CHILDHOOD}

No state in the Union has a more interesting history than Virginia. It is the oldest of the states. It was at Jamestown in 1607 that the first permanent English settlement was made in America. Before the Revolution, it shared with Massachusetts the honor of being the leading colony. During the time of the Revolution, it furnished some of America's greatest leaders Washington, Patrick Henry, and Thomas Jefferson. After the Revolution, it became known as the "Mother of Presidents." Most of the battles of the Civil War were fought on its soil, and its capital was the capital of the Confederacy. Lee and Jackson, the two greatest leaders of the Confederacy, were Virginians.

It was in this state that slavery in North America began. We must remember, however, that slavery had been in existence a long, long time. The ancient Hebrews, we are told in the Old Testament, practiced this evil custom. So did all the nations 
about Palestine. The Greeks and the Romans also kept slaves. We must not think of the people that were enslaved by the Hebrews and Greeks and Romans as negroes. They were of all races. Whenever one people conquered another, it mattered not of what race, the conquerors made their captives slaves. This often resulted in the most cultured and highly educated people being made slaves. This was especially the case when the Romans captured Greeks.

Later on in the history of Europe, during the sixteenth and seventeenth centuries, the enslavement of negroes became very general, so that, by the time North America began to be settled by the people from Europe, negro slaves were bought and sold throughout the principal European countries and their colonies.

So it came about that, in Virginia, negro slavery was introduced into the United States. It was in I6I9 that a Dutch ship, after a cruise in the West Indies, landed at Jamestown, and while there, engaging in trade with the inhabitants, sold them nineteen negroes. These were the first slaves sold in North America, and it was from this beginning that the system grew up in the country.

In Virginia too we had the first big plantations. Tobacco was the most important crop in the early history of the colony. The planters could sell tobacco at a great profit in England. Negro slaves could cultivate tobacco very successfully. 
The planters, therefore, bought slaves to raise tobacco, and they sold the tobacco and bought more slaves to raise more tobacco. The planters bought many hundreds of acres of land and many slaves to cultivate them. As you know, the slaves lived in cabins. These cabins were little houses, usually built of logs, and the cracks were daubed with mud. The cabin usually had one door, one window, and a dirt floor only. These cabins were all close together, not very far from the "big house," and were known as the "quarters."

The slaves did all the work on the plantation. Most of them worked in the fields. Some worked about the barn and in the garden. One drove the master's carriage and took care of the horses. Another was the butler in the "big house." Some of the small boys and girls also worked in the "big house," serving their young masters and mistresses. And, of course, one of the negro women was the plantation cook.

On just such a plantation down in Franklin County, Virginia, Booker T. Washington was born. His mother was the cook on the plantation of a Mr. Burroughs who lived near a little crossroads post office, southwest of Lynchburg, called Hales' Ford. There, in a little one-room cabin, Booker was born on April 5, I 856. The cabin had no glass windows. It had only one door, and it had a dirt floor. There were large cracks that let in the cold. In the middle of the floor 
there was a large opening in the ground in which sweet potatoes were stored. Sometimes as they put the potatoes in or took them out, Booker got one or two and roasted them. All of the cooking was done over the open fire in this cabin, for they had no stove. It was a very uncomfortable place in which to live.

The boy lived a hard life. He says: "I cannot remember a single instance during my childhood or early boyhood when our entire family sat down to the table together, and God's blessing was asked, and the family ate a meal in a civilized manner. It was a piece of bread here, and a scrap of meat there. It was a cup of milk at one time and some potatoes at another."1

One day, when he was about five years old, he saw his young mistress and some visitors out in the yard eating ginger cakes. He said he never saw anything in his life that looked so good to him as those cakes did; and he thought that, if he ever got free, the height of his ambition would be to buy all the ginger cakes he wanted, just like those the young ladies were eating.

He had to sleep on a pallet. He never slept in a bed until after he was set free. The first pair of shoes he ever had was made of leather, but the soles were of wood, and they were very uncomfortable and made a great noise when he walked. He never thought of wearing anything on his head. 1 "Up from Slavery," by Booker T. Washington, p. 9. 


\section{EARLY CHILDHOOD}

But the worst thing about his dress in those early days was having to wear a flax shirt. These shirts were made of the roughest and coarsest part of the flax, and they were very uncomfortable. When new, they scratched severely. After they were worn awhile and "broken in," they were fairly comfortable. His brother John often "broke in" Booker's shirts for him, a very kind and generous thing to do.

He had no time to play when he was a boy. When he was a grown man, he was asked what games he played when he was a boy, and he answered that he had never played at all. He had to work so hard that no time was left for play. Even when he was a very small boy, he had to sweep the yards, carry water to the hands in the fields, help around the "big house," and carry in wood. Going to mill was the worst job he had. $A$ farm hand would put a sack of corn on a horse, put him on top of the sack, and send him off. Ic was a long way to the mill. Almost every time he was sent, the sack of corn would work to one side and then fall off. It was too heavy for him to put back; so he would have to wait until some one came along to help him. He sat and cried until some one came. It was often dark when he got home. He was terribly frightened when he was alone at night, for he was told that there were deserting soldiers in the woods, and that when they found little negro boys the first thing they 
would do would be to cut off their ears. Of course this was not true, but he thought it was.

Do you suppose this little boy had any chance to go to school? This is what he says: "I had no schooling whatever while I was a slave, though I remember on several occasions I went as far as the schoolhouse door with one of my young mis-

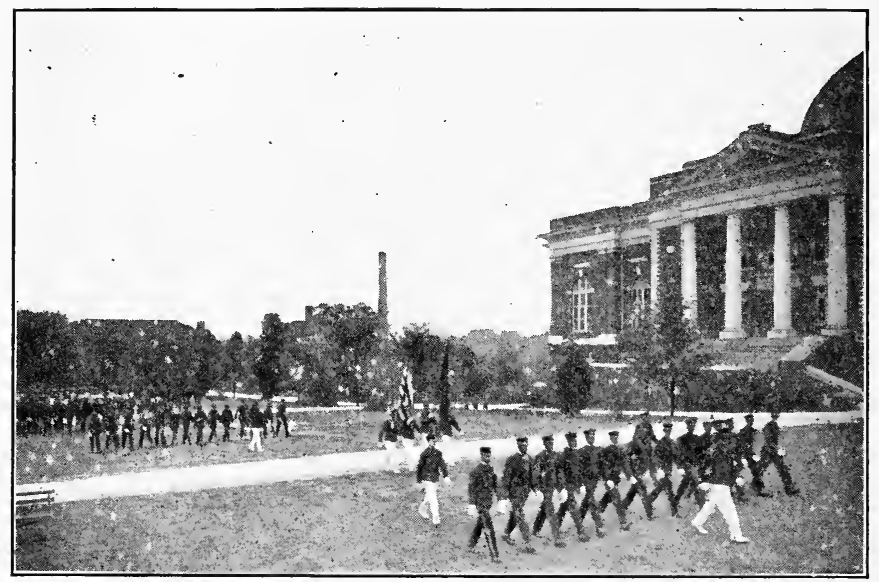

Founder's Day Drill at Tuskegee

tresses to carry her books. The picture of several boys and girls in a schoolroom engaged in study made a deep impression upon me, and I had the feeling that to get into a schoolhouse and study in this way would be about the same as getting into paradise." 1 This is the same boy who came to be the greatest educator of his race: the head of the greatest negro school in the world.

1 "Up from Slavery," by Booker T. Washington, pp. 6-7. 
It must be remembered that the conditions under which Booker lived in these early years of his life were not restricted entirely to the negroes. Many of the white people were poor also, and many white boys wore flax shirts and shoes with wooden soles. Just after the Civil War, especially, all the white people of the South had a very hard time. White boys as well as negro boys had no time for play. Nor did they have an opportunity to go to school. In those days many white boys who were eager for an education had such difficulties to face as those which loomed up before Booker Washington.

By and by, when Booker was about nine years of age, there came a thrilling day. For four long years the great war had been going on. Often he had heard his mother singing freedom songs. He remembered being awakened one morning and saw his mother by his bed and heard her praying that Lincoln might be successful, and that her little boy might some day be free. He had seen some of the soldiers in their uniforms, home on furlough. He remembered when they brought home the body of "Marse Billy" and buried him amidst the bitter weeping of the slaves, who loved him as their friend, for he had often begged for them when they were about to be punished. While they vaguely knew and felt that the success of Lincoln meant freedom, and the success of the others meant slavery, they, were still loyal and 
true to their masters. By means of the "grape vine telegraph," that is, by passing news along quickly from one plantation to another, the slaves had kept pretty well informed of the progress of the war, and when Lee surrendered at Appomattox, the slaves knew it very soon.

One night word came to the "quarters" that something very unusual would happen at the "big house" the next day. There was much excitement. Nobody slept that night. Early next morning some one came to the quarters and told the negroes that they were all wanted at the house. Booker's mother called her children, and they with all the other slaves marched up to the house. All the members of the family were on the porch. They were very quiet and seemed sad and depressed. There was present a stranger, a man who wore a uniform. He stood up and read a paper "The Emancipation Proclamation." Then the master explained that the negroes were now free. He told them that they could go wherever they desired. He also told them that they could live where they were if they wanted to, and they would be taken care of; but if they preferred, they could go to any other place. Booker's mother leaned over her children and kissed them while the tears streamed down her face. Her prayers had been answered. Her children were free. 


\section{CHAPTER II}

\section{BOYHOOD DAYS}

WHEN the slaves were set free, one of the first things that many of them did was to change their names. Most of the slaves had only one name. As free people they felt that they should have the same sort of names as other free people; so they began to add a last name, and usually an initial. If a man had been called "Tom" all his life, he was now called "Tom L. Johnson." The "L" stood for nothing. It was simply a part of his "entitles," as Washington says. Another thing they did was to leave their old home place. They could not realize that they were really free unless they tested the matter by going away from the place of their servitude.

Booker Washington's stepfather had left Virginia during the war and had gone to West Virginia. Just as soon as the war was over, he sent for his wife and children to come to him in West Virginia.

He lived at Malden, five miles from Charleston, the capital of the state. It was several hundred miles from the old home in Virginia, but the family determined to go. They bundled up their goods and put them in a cart, the children walking. They traveled the entire distance in this way. 
They would stop by the roadside to do their cooking and to camp at night.

One night they stopped near an empty cabin. They decided to spend the night in the cabin. They went in and built a fire and spread a pallet on the floor. Suddenly a big black snake rolled down out of the chimney and on to the pallet. You can imagine that they did not care to stay longer in that house. They got outside at once and made a camp.

After several weeks, they completed their journey, and the family reached the town of Malden. Salt was mined there, and Booker's stepfather worked in the salt furnaces. Small as he was, Booker had to begin this work too. It was very hard work, and it was terrible that this child should be compelled to do it. But it was just like Booker to turn the situation to an advantage. The first thing he ever did in the way of reading was to learn the figure "I 8 ," which was the number put on the barrels of salt made by his father. Booker was anxious to learn to read; but he had no one to teach him. His own mother could not even teach him his letters. She bought him an old Webster's "blue-back" speller, and he began his first study in this book.

About this time a private school was established in the community. Booker was greatly excited over this, for he had an overwhelming desire to go to school. He was a good worker, however, and 


\section{BOYHOOD DAYS}

was earning money; so his father said "no," and he could not go. Booker was terribly disappointed. He went on with his work with a heavy heart, but he never missed a chance to urge his stepfather to let him go to school. Finally, his father agreed to let him go for a part of the day, provided he would get up early each morning and work until nine o'clock and then work two hours after school was out.

It was a glorious day for him when he found himself going to school. However, he soon encountered two great difficulties. One was that he did not have a hat. He had never worn a hat or cap in his life. Since all the other boys had them, he felt that he must have one. So he went home and told his mother about the situation. She explained to him that she had no money with which to buy a "store" hat, but she got two old pieces of "homespun" or jeans, and sewed them together for a cap. The next day Booker proudly walked to school with one difficulty solved.

Listen to his own story of his second difficulty: "My second difficulty was with regard to my name, or rather a name. From the time I could remember anything I had been called simply 'Booker.' Before going to school it had never occurred to me that it was needful or appropriate to have an additional name.

"When I heard the school roll called, I noticed that all the children had at least two names, and 
some of them indulged in what seemed to me the extravagance of having three. I was in deep perplexity, because I knew that the teacher would demand of me at least two names, and I had only one. By the time the occasion came for the enrolling of my name, an idea occurred to me which I thought would make me equal to the situation; and so, when the teacher asked me what my full name was, I calmly told him 'Booker Washington,' as if I had been called by that name all my life; and by that name I have since been known. "Later in my life I found that my mother had given me the name of 'Booker Taliaferro' (pronounced Tol-li-ver) soon after I was born, but in some way that part of my name seemed to disappear, and for a long while was forgotten, but as soon as I found out about it, I revived it and made my full name 'Booker Taliaferro Washington.' I think there are not many men in our country who have had the privilege of naming themselves in the way that I have." 1

Booker was not permitted to go to school very long. His stepfather put him back to work but he went to school at night for a while. Here he learned how valuable the nighttime was, and he afterwards used it a great deal in teaching others.

Near Malden was a coal mine. This business became prosperous, and Booker was sent to work in the coal mines. He hated this work worse than

1 "Up from Slavery," by Booker T. Washington, pp. 34-35. 


\section{BOYHOOD DAYS}

any he ever did. The work was very dirty. It was pitch dark in the mines. It was also very dangerous, for they used dynamite to blast out the coal. His work was a mile from the entrance of the mine. Furthermore, there were many big rats in the place. Because there were many large chambers to the mine and he never could learn all of them, he often got lost. Then his light would go out, and sometimes he would have to wait for hours for some one to come to his aid. This was terrible work for a boy only ten or twelve years of age. 


\section{CHAPTER III}

\section{PLANNING FOR AN EDUCATION}

LATER in life Washington said: "There was never a time in my youth, no matter how dark and discouraging the days might be, when one resolve did not continually remain with me, and that was to secure an education at any cost." 1

This was the thought that was in his mind as he toiled from day to day in the dark and dirty coal mine. He had never heard of any school except the little one he had attended for a short time in Malden. But he was sure that somewhere and in some way he would find a place that would give him what he so much desired.

One day, while digging away in the mine, he heard a miner say something to another about a big school for negroes. He was greatly excited and on his hands and feet he crept through the dark, as close to the two men as he dared, and listened. They kept on talking and Booker heard a conversation something like this: "I wish my boy could go to that school over in Virginia," said one miner. "They say it is the best school anywhere in the country.'

"What'school are you talking about?" said the other.

1 "Up from Slavery," by Booker T. Washington, p. 37. 


\section{PLANNING FOR AN EDUCATION 15}

"'The one at a place called Hampton, over in Virginia," was the reply.

"Well, suppose there is a good school there; negro boys can't go to it, can they?" was asked.

"Yes, they can," said the other. "It is a school just for negro boys and girls, and they teach the boys and girls something besides books, too. They are taught some useful trades so that they can go out and make a good living and be independent and have pleasant work to do."

"Well," said the other miner, "that sounds pretty good, but nobody but rich folks can afford such a school as that; so I don't see where it is going to help us any.'

"There is where you are mistaken again," was the answer, "for poor boys and girls can go to this school. That is what I have heard. They say that they give the boys and girls different kinds of work to do, so that they can pay their own way through school.'

Booker heard no more. He returned to his work very greatly excited. That certainly was the place for him. He then and there made up his mind that he would go to that school no matter what happened. He did not know where the place was, but he determined that he would find it. From that day on, one thought was in his mind - to go to Hampton.

He wanted to quit work in the mines, because the work was so dangerous, and because he was 
not making enough money. A few days after he heard the conversation about Hampton, he heard that Mrs. Ruffner wanted a servant. She was the wife of General Lewis Ruffner, the owner of the salt furnaces and the coal mines. The lady, Mrs. Viola Ruffner, was said to be very strict with her servants, and consequently no servant would stay with her long at a time.

When Booker heard that she was looking for another servant, he decided to apply for the place. He was terribly frightened when he went into her presence; and he was surprised to find her very kind and considerate. She employed him, giving him five dollars a month. She became very fond of this boy, who worked so hard and so well and tried to do the work so as to please her. She showed her interest in his ambition to get an education, by letting him off a part of the day to study, and by encouraging him to go to the night school.

Washington says also that he learned from Mrs. Ruffner many valuable lessons in cleanliness, promptness, and order. He says: "Even to this day, I never see bits of paper scattered around a house or in the street that I do not want to pick them up at once. I never see a filthy yard that I do not want to clean it, a paling off a fence that I do not want to put it on, an unpainted or unwhitewashed house that I do not want to paint or whitewash it; or a button off one's clothes, or a grease 
spot on them or on a floor, that I do not want to call attention to it." 1

It was while working for Mrs. Ruffner that he started his first "library." He got an old drygoods box, knocked out one side of it, nailed it up against the wall, arranged some shelves, and then put into it every book that he could lay his hands on.

But Booker was restless. He wanted to get started to school. He had not saved much money, for he had not been working for himself very long, but he determined to start with what little money he had.

What did his determination mean? Look at your map and you will see that Hampton is about five-hundred miles from Malden. Booker was a boy of sixteen years. He did not know a soul beyond the borders of his own community. He had but a few dollars. His mother was not well, and he doubted very much whether he would ever see her alive again. But he must go and learn, and his good mother, noble and brave as she was, encouraged her boy and helped him to get away.

All the people in the community were much interested in his going. While they had never had a chance, they wanted to encourage this boy who was so determined to get an education. Some of them would give him a nickel, some a quarter, and others a handkerchief to show their desire

1 "Up from Slavery," by Booker T. Washington, p. 44. 
to help him. By and by the day for his departure came. He put his few dollars in his pocket, picked up the little satchel containing his few clothes, said good-by to the neighbors, kissed his weeping mother good-by, and turned his face towards Hampton.

There was no through train in those days, and he had to travel by stagecoach as well as by train. He had no idea, when he started, how costly it was to travel, and he had not gone far before he realized that he did not have enough money to take him to Hampton. So he walked much of the way. He would ask for a ride with passers-by, and in this way made fairly good progress.

Early in his journey he had a new and trying experience. He had been riding, together with a number of white passengers, all day in the stagecoach. At nightfall they stopped at a house which was called a hotel, and all the passengers went in and were given rooms. When Booker went in and asked for a room, he was told that they could not take him, that they did not take negroes. He had not intended to offend. He himself says it was simply the first time that he realized that the color of his skin made a difference. He was so intent upon getting to Hampton, he never thought of getting angry. He simply walked about all night, as it was rather cold, and went on his journey next morning.

Let him tell his own story of another incident 
of this famous journey. "By walking," he says, "begging rides both in wagons and in the cars, in some way, after a number of days, I reached the city of Richmond, Va., about eighty-two miles from Hampton. When I reached there, tired, hungry, and dirty, it was late in the night. I had never been in a large city, and this was rather to add to my misery. When I reached Richmond, I was completely out of money. I had not a single acquaintance in that place, and being unused to city ways, I did not know where to go.

"I applied at several places for lodging, but they all wanted money, and that was what I did not have. Knowing nothing else better to do I walked the streets. In doing so, I passed by many places and foodstands where fried chicken and half-moon apple pies were piled high and made to present a most tempting appearance. At that time it seemed to me that I would have promised all that I expected to possess in the future to have gotten hold of one of those chicken legs or one of those pies. But I could not get either of these, nor anything else to eat.

"I must have walked till after midnight. At last I became exhausted and I could walk no longer. I was tired. I was hungry. I was everything but discouraged. Just about the time when I reached extreme physical exhaustion, I came upon a portion of the street where the board sidewalk was considerably elevated. I waited for a 
few minutes, till I was sure that no passer-by could see me, and then crept under the sidewalk, and lay for the night upon the ground with my satchel for a pillow." 1

When he awoke in the morning, he found that he was near a large ship which was unloading a cargo of pig iron. He went directly to the ship, told the captain his situation, and asked for work in order that he might earn money with which to buy some food. The captain gave him work and was so well pleased with him that he gave him employment for several days. Washington was anxious to get enough money to take him to Hampton as soon as possible. So in order to save as much of his wages as possible, he continued to sleep under the sidewalk where he slept the first night he arrived.

Many years after that, he was given a great reception in Richmond, at a place near this spot, and Washington says that his mind was more upon that sidewalk that night than it was upon the great reception given him by the two thousand people present.

After a few days of work in unloading the vessel, he felt that he had enough money to take him to Hampton; so he continued his journey. Several days later he reached Hampton, with just exactly fifty cents.

What a wonderful journey it had been! And 1 "Up from Slavery," by Booker T. Washington, pp. 48-49. 


\section{PLANNING FOR AN EDUCATION 2I}

now at its end, as the big buildings of the school came into view, he had a thrill that more than repaid him for all the hardships of his trip. He was supremely happy, for he had reached the end of his rainbow and had found his great treasure. 


\section{CHAPTER IV}

\section{SCHOOL DAYS AT HAMPTON}

AT the close of the Civil War one of the most important needs of the country was to provide some kind of education for the negroes. They had never had any schools. If they were to become good citizens, they must have the proper training. A great many good men in the North and in the South recognized this fact, and set to work to establish schools. Among these men was General Samuel C. Armstrong. The General's parents had been missionaries to Hawaii. He had been educated in the United States, had entered the army as soon as the war began, and had made such a brilliant record as a soldier that, when the war was over, he had risen to the rank of general.

He had seen a great deal of the negro as a soldier during the war. He knew about the conditions in the South, and he felt that the greatest scrvice he could render would be to give his life to the cause of education. He went to work at once, and, through the aid of a number of Southern men, he established a school for negro boys and girls at Hampton, Virginia, and called it Hampton Institute.

His main purpose was to give negro boys and 
girls an opportunity to learn some useful trade. He believed that people must first learn to make a good living before they could make much progress in any other direction. He wanted the negroes to have good food and good clothes and good homes. He wanted them to be able to earn these

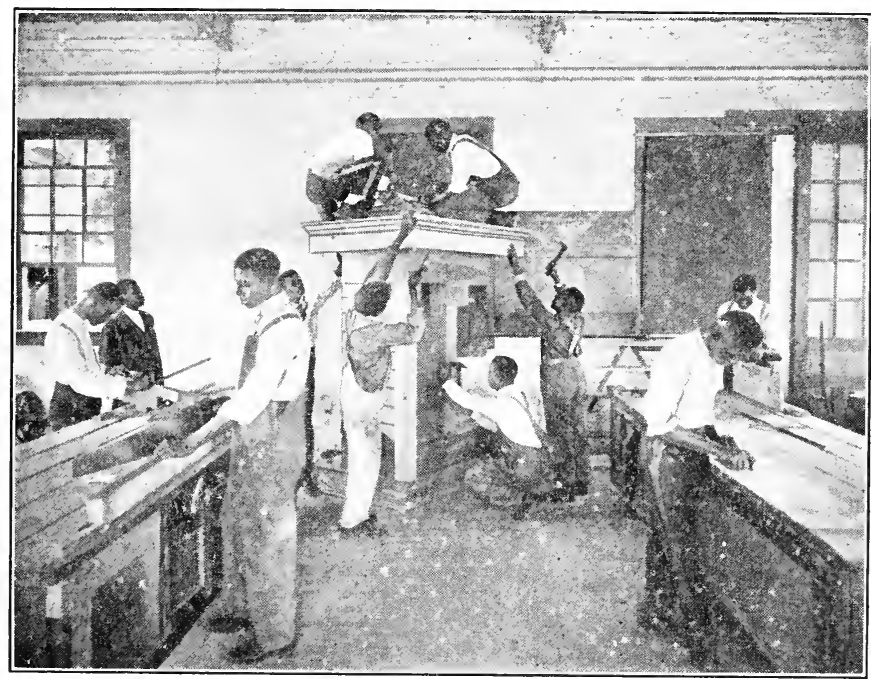

Cabinetmaking at Tushegee

things. Likewise, he wanted them to be good farmers, good carpenters, good brick masons, good mechanics, and good workmen in all kinds of trades. He wanted these trades taught in the schools. Then, as the race progressed, he wished to have the higher branches of study given, such as Latin, mathematics, and literature. 
Thus was begun one of the greatest schools in America. Every negro boy knows about Hampton. Thousands of the best negroes in the country were trained there. General Armstrong was president of the school and did a wonderful work. He

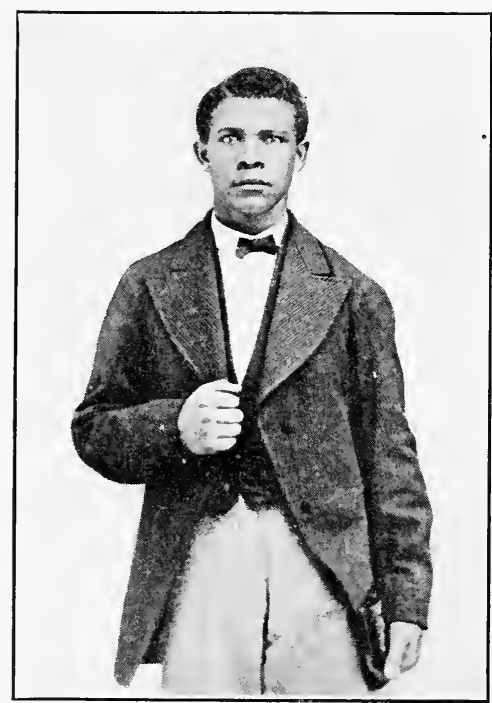

Booker T. Washington AS A Hampton Graduate (I875) seemed to inspire every student who entered to become a good and useful citizen. Too much cannot be said in praise of him and the great school he founded.

It was here that Booker arrived in the fall of $\mathrm{I} 872$, with a little satchel of clothes, fifty cents in his pocket, a happy heart, and a determination to succeed.

Just as soon as he was able to get an interview, he went to the head teacher, Mary F. Mackie, and told her that he wanted to enter school. She stared at him. He was dirty after his long and hard journey. His clothes were soiled. He realized at once that he was making a bad impression, and it was not his fault. Miss Mackie would not say 
whether she would admit him or not. She made him wait. He was worried. All he wanted was a chance to show her that he meant business. Then a very interesting thing happened. Booker Washington tells the story himself. He called it his examination.

"After some time had passed," he says, "the head teacher said: "The adjoining recitation room needs sweeping. Take the broom and sweep it.'

"It occurred to me at once that here was my chance. Never did I receive an order with more delight. I knew that I could sweep, for Mrs. Ruffner had thoroughly taught me how to do that when I lived with her.

"I swept the recitation room three times. Then I got a dusting-cloth and I dusted it four times. All the woodwork around the walls, every bench, table, and desk, I went over four times with my dusting-cloth. . Besides, every piece of furniture had been moved and every closet and corner in the room had been thoroughly cleaned. I had the feeling that in a large measure my future depended upon the impression I made upon the teacher in the cleaning of that room.

"When I was through, I rapped on the door, and reported to the teacher. She was a 'Yankee' woman who knew just where to look for dirt. She went into the room and inspected the floor and closets; then she took her handkerchief and rubbed it on the woodwork about the walls, and 
over the table and benches. When she was unable to find one bit of dirt on the floor, or a particle of dust on any of the furniture, she quietly remarked, 'I guess you will do to enter this institution.'

"I was one of the happiest souls on earth. The sweeping of that room was my college examination, and never did any youth pass an entrance examination into Harvard or Yale that gave him more genuine satisfaction. I have passed several examinations since then, but I have always felt that this one was the best one I ever passed." 1

As a result of his sweeping the room, he was permitted to enter his classes and was also given a job as janitor, and his college career began. It was a new, strange life. He sat down at a table, which had a cloth on it, to eat his meals. He slept in a bed that had sheets on it. These sheets gave him trouble. The first night he slept under both of them. He didn't think that was right, so the next night he slept on top of both of them. The third night he watched his roommates, there were seven of them in the same room, - and he saw how the thing was done. After that, he did as the others did and slept between the sheets.

"I sometimes feel," he says, "that almost the most valuable lesson I got at Hampton Institute was in the use and value of a bath. I learned there, for the first time, some of its value was not only 1 "Up from Slavery," by Booker T. Washington, pp. 52-53. 
in keeping the body healthy, but in inspiring selfrespect and promoting virtue. In all my travels in the South and elsewhere since leaving Hampton Institute, I have always in some way sought my daily bath. To get it sometimes when I have been the guest of my own people in a single-roomed cabin has not been easy to do except by slipping away to some stream in the woods. I have always tried to teach my people that some provision for bathing should be a part of every house." 1

For some time he had only one pair of socks. He had a time of it with these socks. When they were too soiled to wear, he would wash them out at night, hang them by the fire and dry them out, and put them on the next morning. He also had a hard time with his clothes. They had inspection every morning. The students were lined up, and General Armstrong passed along the lines and carefully examined every one. If a button was off, or if the clothes were torn or soiled in any way, the General would see it. Booker had a hard time keeping his clothes in such a condition that they would pass muster.

His work as janitor was very hard. He often had to work late at night, for he had many rooms to clean. He always got up at four o'clock in the morning to build his fires and do some of his studying. He had a hard time working and making expenses too. He usually borrowed his books from

1 " Up from Slavery," by Booker T. Washington, p. $5^{8}$. 
other students. He soon got some more clothing from the barrels of clothing sent to the school by people from the North. Board was ten dollars a month, part of which he could pay by his work as janitor, but a part of it he was supposed to pay in cash, and he had no cash. His work was so satisfactory, however, that in a short while he was told that his work would pay all of his board. S. Griffitts Morgan, of New Bedford, Massachusetts, paid his tuition. At the end of the year he owed the college only sixteen dollars.

When the college closed at the end of the term, all the students went home. Booker could not go. It was too far, and he had no money. He wanted to get away and get a job, so that he could pay the sixteen dollars he owed. He had an extra secondhand coat; so he decided to sell that to get money to go away on. He cleaned and pressed the coat, and then let it be known that it was for sale. After a while a man came to see it. He looked at it and asked the price. Booker told him three dollars. The man said, "Well, I think I will take it. I will tell you what I will do. I will pay you five cents cash, and the rest as soon as I can get it," How do you suppose Booker felt about that?

He finally got a job as a waiter in a restaurant at Fortress Monroe. They did not pay him enough for him to save anything. One day when he was cleaning up the place, he found a nice, crisp tendollar bill under a table. He was very happy. 
Now he could pay back the money he owed at Hamptor. However, he thought he ought to tell the proprietor about finding the ten dollars. He did so, and the proprietor coolly took the ten-dollar bill, saying that, since the place belonged to him, everything that was found in it naturally belonged to him.

After vacation was over, he returned to Hampton and was told that he could have as long to pay the sixteen dollars as he wanted, and that he could have a job as janitor again. So, his second year passed much the same as the first. He devoted much of his time this year and the next to the debating societies. He says that he never missed a single meeting while he was at Hampton. He also organized a new society. He had twenty minutes every night after supper before work began. Most of the students, he observed, wasted this time. He proposed that good use be made of this period in reading and speaking, and he organized a society for that purpose. He says that no time he spent in college was more valuable than this.

After the close of his second year, he went home to Malden to spend his vacation. His brother John had sent him some money, and he had earned some extra money. So he had enough to take him home. Everybody was delighted to see him, but most of all, his mother. All the neighbors insisted on his visiting them and taking a meal with them 
and telling all about his college days. He also spoke at Sunday schools, at the day school, and at churches, telling about his life at Hampton.

This was all very nice, but he wanted some work, so that he could earn enough to take him back to Hampton in the fall. He was unable to find any work because the salt furnaces and the coal mines were closed. One day he went further than usual looking for something to do but without success. On his way home he became so tired that he went into a deserted cabin by the road to spend the night. About three o'clock some one woke him up. It was his brother John, who told him that their mother had just died.

This was a terrible shock to Booker. He had had no idea his mother was so ill. He had always wanted to be with her and care for her. He had looked forward to the time when he might make enough money for her to live in comfort. He loved her very dearly, and her death was the hardest blow he had ever received.

It was not long after this that he got some work and saved enough money to take him back to Hampton. During his third year at college he worked harder than ever. He was still working as janitor, but every single minute he had after his work was done he spent on his studies. College boys in those days did not have time to play football, baseball, and tennis. They did not have time to go on picnics or have dances. 


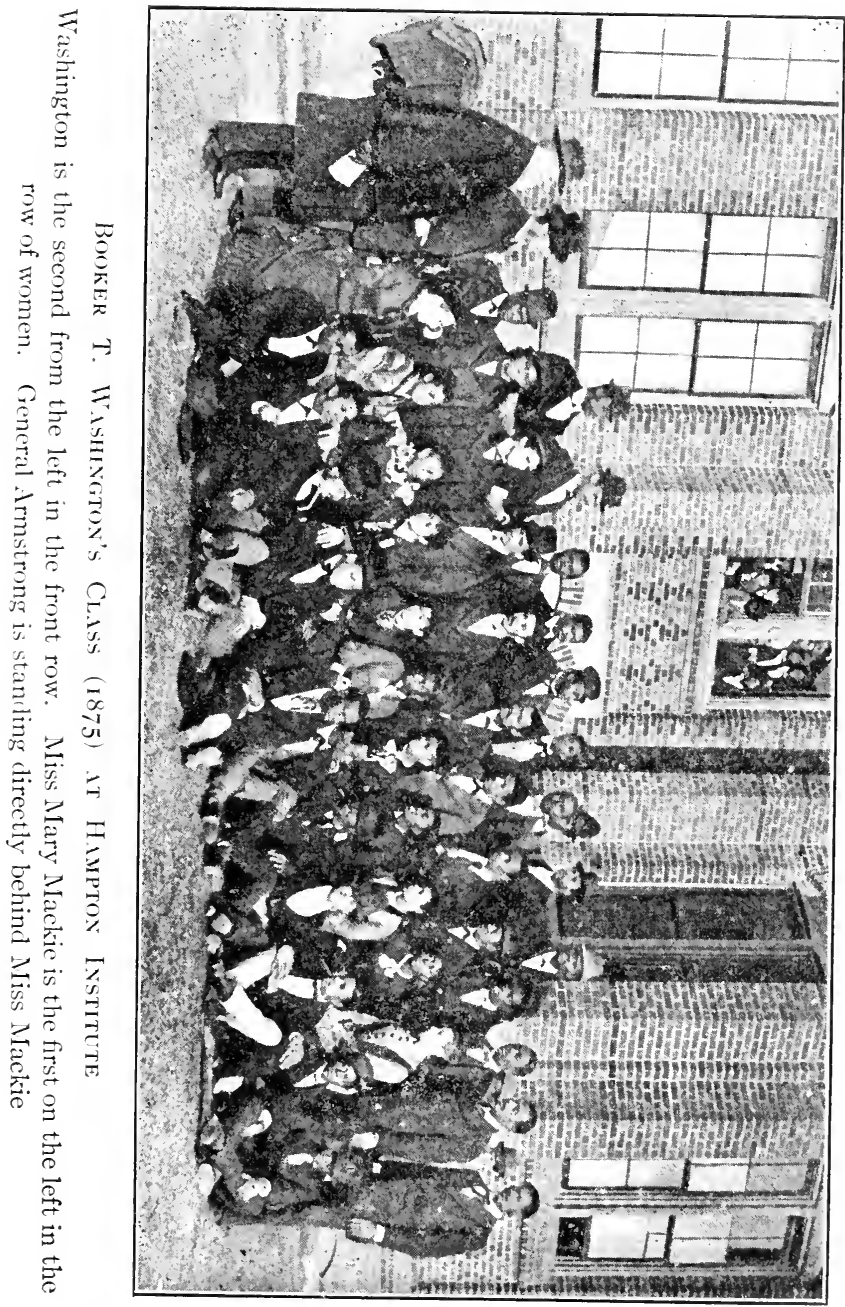


The highest honor at Hampton was to be selected as commencement speaker. This honor Booker was anxious to win. He worked very hard for it, and, when commencement day came in June, I875, he sat on the platform among the honor men of his class as one of the orators. $\mathrm{He}$ was given his diploma, and his college days were over.

He had done a good job. He had done the kind of work that makes real men. He had trained his mind and his hands. He had built character. He was not ashamed. He could hold his head up and look the world in the face. He had learned to help himself. He was independent and had gained self-confidence and self-control. He knew little of Latin, but he knew much of labor. He knew no Greek, but he knew how to dig. He knew the soil. He knew people. He was ready for the great work that lay before him. 


\section{CHAPTER V}

BEGINNING LIFE IN THE OUTSIDE WORLD

General Armstrong handed Washington his diploma in June, I875, and he walked forth from the college walls a very proud and happy boy. He had a right to be. No boy had ever striven harder for an education. For three years, day and night, he had worked, as few people ever had. But he had enjoyed it. Don't get the idea that Washington was discouraged or that he was unhappy, for he was not. He got an immense amount of genuine satisfaction and pleasure out of his school days. His teachers were good to him, and he was devoted to them. His classmates were always kind to him and helpful and thoughtful. Everybody was his friend. No boy ever left Hampton with more warm friends, was more beloved by students and faculty, than Booker Washington. And these friendships were truly worth winning, because they were greater and better than anything else in the world.

One of the fine things about Washington was his independence. He knew how to take care of himself. He knew he could make his own way in the world. He was unusually robust, because he had always taken good care of himself. With health, 


\section{4

with an education, and with an overwhelming desire to help his people, he left Hampton and started his life in the outside world.

Washington left Hampton in exactly the same financial condition as when he entered. He had a diploma in his pocket but no money. However, he was not ashamed of work, if it was honorable, and he was not afraid of any amount of it. Along with some other Hampton boys, he was offered a job in a summer hotel in Connecticut.

When he began his new work, he had an embarrassing experience. The head waiter, somehow, got the idea that he had done this kind of work before. He sent him to serve at a table where several rich people were seated. Washington was very awkward and confused, and the people scolded him soundly. It frightened him so that he went away and would not return to the table, leaving the guests without anything to eat.

For this offense, the head waiter reduced him from his position as waiter and put him to washing dishes. Thereupon, he made up his mind that he would learn to do this job well. So successful was he that the head waiter soon put him back at serving, and he made one of the best waiters in the hotel.

When his summer's work was done, Washington returned to his old home at Malden. Soon after his arrival, he was chosen to teach the school there. He accepted the place and began the work at once. 
He taught this school for two years, and it is doubtful if he ever did better work in his life than during these two years.

All his life the idea had been in Washington's mind that he must help his people. This was what he wanted most to do. This was why he wanted an education. Many people want an education for selfish reasons, such as, to make money for themselves, to have an easy time or to get honors for themselves, but this was never true of Booker Washington. His great desire was to help his people. He looked about him and saw how poor and helpless and ignorant they were, and his heart was touched. He wanted to do something that would make his people better and happier.

Now he had his first chance. He went at his work with great joy. He opened his school at eight o'clock in the morning, and he usually quit work about ten o'clock at night. He taught the children reading, writing, geography and arithmetic, but he taught them something else too. He made them comb their hair. He made them keep their hands and faces clean. He taught them to keep their clothing clean. He taught them to use a toothbrush, and to know the value of a bath.

He organized a debating society for the men and boys. He opened a night school so that those who worked and could not go to school during the day could go at night. He established a reading room. He taught several boys privately in order to get 
them ready to enter Hampton. He taught in two Sunday schools. In fact, he did more to make his community a good, clean, happy community than anybody had ever done before.

One of the good things he did was to help his brother John who had helped him so much while he was at Hampton and now wanted to go to school himself. What a joy it was to Booker to be able to do something for this kind and generous brother! John did go to Hampton, as did another brother, James, who was an adopted child; and both helped Washington loyally in later years at Tuskegee.

After teaching two years at Malden, Washington decided to go to school again. This time he went to Washington, D. C., and entered Wayland Seminary, where he remained eight months. He did not care so much for his work here. It was very different from the work at Hampton. The students were all well dressed. They did not have to work as they did at Hampton. They had plenty of money, and their studies were different. They did not have trades, industries, agricultural work, or dairying, or anything of that kind. They had Latin and Greek and literature and higher mathematics and other studies of a similar kind. Washington felt that he did not get the benefit that he did at Hampton.

Nor did he like Washington any better than he liked this school. He saw too much extravagance 
to suit him. Too many people were trying to get something for nothing. Too many of them were trying to get jobs with the Federal Government that would be easy work and high pay. Many of the negroes seemed to think it was the business of the Federal Government to support them. Washington did not think this was right. $\mathrm{He}$ thought all men should do good, honest work, and that, if they didn't, they would sooner or later find trouble. He was glad to get away, for he felt that the life that most of the negroes lived at that time in Washington was most unsatisfactory.

At the end of the eight months, he returned to Malden again. At this time there was a big campaign on in West Virginia to remove the capital, which was located at Wheeling. It was far up in the northern part of the state. Many of the people wanted another city to be chosen. The legislature selected three cities to be voted upon by the people and Charleston was one of these. Malden, you remember, was five miles from Charleston. Just after he returned from Washington, Booker was greatly pleased to receive an invitation from a committee of white men to come to Charleston and then go on a speaking tour in behalf of that city. He accepted the invitation, and for three months he went about the state speaking for Charleston as the capital. When the election was held, Charleston won; and no small part of the credit was due to the brilliant 
speeches made by the young negro teacher of Malden.

He made such a reputation as a speaker in this campaign that everybody took it for granted that he would now study law and enter politics. A well-known judge tried to persuade him to do this and offered to teach him law. This was very flattering, and for a while Washington considered it. But all the time he had the feeling that there was something else he must do. He felt that he could succeed in law and politics, but he also felt that it would be selfish; that he would be doing something largely to benefit himself only.

Most of the negro men in politics, at that time, were vicious and ignorant. Of course there were many exceptions; but, as a general thing, the negro who was in politics during that period was uneducated and often dishonest. Washington tells of passing a crowd of men one day as they were at work on a building. He heard the men saying to one of the others, "Hurry up, Gov.," and "Hurry, Governor." He paid no attention at first but finally made inquiry and found that the negro spoken to had at one time been the lieutenant governor of the state.

Washington felt that the greatest thing he could do was to engage in the kind of work that would help his own people most. He did not want to preach. He thought there were too many preachers already. He had the belief that the most 
important thing to do was to engage in the kind of work that would fit men of his own race to be good preachers, good teachers, and good citizens.

In the midst of these thoughts, and before he had definitely made up his mind as to his career, he received a letter from General Armstrong, inviting him to deliver the "postgraduate" address at Hampton at commencement, I879. This honor brought Washington great joy. He accepted the invitation and chose as his subject, "The Force That Wins." He worked hard for three months on his speech. It made a great impression on all who heard it, and he was acclaimed one of the real orators of his race. 


\section{CHAPTER VI}

\section{BACK AT HAMPTON}

THERE is an old saying that "opportunity knocks but once" upon our door. This is not true. Opportunities will certainly continue to come to us. The important thing is to be ready for them when they come. We never know what incident may turn out to be our greatest opportunity. If we will do our best to meet every situation that confronts us, we may be sure that there will be plenty of opportunities for us. It is the boy that does not do his best on all occasions that loses out. So Wasnington, when invited to speak at Hampton commencement, worked hard for three months preparing that speech. When the time came, he did his very best. Then he forgot the matter and went home. Just a few days after he got home, he had a great surprise. There came a letter to him from General Armstrong. It said, "We need you here at Hampton. We want you to come and help us run the school."

That was a very happy moment in the life of Washington. He thought more of General Armstrong than of any other man in the world. To be asked by this man to come and work for him 
made Washington an exceedingly happy man. He immediately wrote that he would accept the position. Some weeks later he reached Hampton, ready to enter upon his new duties.

His job was a rather peculiar one. The Indians in the United States, who had been put upon certain territories out West, after being taken from their land in the South and Southwest, had no system of education and were entirely without schools of any kind.

General Armstrong wanted to help them. He said he believed that they could be educated, and he wanted to try it. The Government of the United States gave its consent and agreed to cooperate with him.

They brought from the West to Hampton about one hundred Indian boys to be educated. These boys were very ignorant; Booker Washington says that they were almost wild.

Washington's task was to live in the same building with these Indian boys and look after them to be a sort of "house father" to them.

He had a hard job. The Indians are a very proud people. They felt themselves superior to the white race, as well as to the black race. They had a special dislike for the negro because he had been a slave, and the Indians would not be slaves; they preferred death to slavery.

These boys were not only very ignorant, but it was very hard to make them understand, 


\section{2 \\ BOOKER T. WASHINGTON}

as they did not know the English language well. Furthermore, everybody expected them to fail.

We usually do just about what people expect of us. If they think we are going to succeed, it helps us to succeed. If they think we are going to fail, it makes attainment of success harder for us. Booker Washington said: "I will succeed. I will show these people that these Indians can be educated." So for an entire year he worked with them. He soon won their confidence and respect. That they all liked him was evident, for they did everything they could to satisfy him and please him. He found them ready to work hard and intelligent enough to be taught. They learned the different kinds of trades just about as well as the negroes did. At the end of the year everybody was willing to admit that Washington had made a success of teaching the Indians. Ever since then Indians have been going to Hampton, and many of them are students there to-day.

Washington says his hardest task was to get them to give up some of their old habits and customs. They did not want to part with their long hair; they did not want to quit wearing blankets or quit smoking. However, since these customs were not customs at Hampton, they all agreed to do as the others did there.

Now came another very important work for Washington. After he had worked with the 
Indians for a year, General Armstrong said, "I have another hard job for you."

"Show it to me," Washington replied.

A great many people who did not have any money were trying to enter Hampton; they were as poor as Washington was when he entered. General Armstrong did not want to turn them away. He finally determined that he would arrange it so these people could work all day at some trade or other line of work and thus pay their living expenses and have something left over to go into the treasurer's office to their account. They had to work ten hours a day to do this. Then they went to school two hours at night. After a year or two they would have enough money saved up from their work to enable them to enter the day school. This plan proved to be a very fine one, and many of the best students from Hampton began in the night school.

It was this night school that General Armstrong wanted Washington to teach. He took charge of it and made a great success of it. There were about twelve in the class to begin with. The boys worked in the sawmill in the daytime, and the girls in the laundry. They were such good workers that he named them the "Plucky Class." After a boy or a girl had been in this class long enough to show that he or she meant business and was going to stick to the job, Washington would give a certificate that read as follows: 
"This is to certify that James Smith is a member of the Plucky Class of the Hampton Institute and is in good and regular standing." 1

The students were very proud of these certificates. It was not long before everybody at Hampton was talking about the "Plucky Class." In a little while there were twenty-five in the group. The number kept on growing the next year, and in a few years the class had several hundred members. It is a big part of Hampton and Tuskegee to-day, for Washington used the same idea at Tuskegee.

Washington had a way of succeeding in everything he undertook. This was because he determined to succeed and worked so hard and so well that success was certain.

1 "Up from Slavery," by Booker T. Washington, p. 105. 


\section{CHAPTER VII}

\section{BUILDING A GREAT SCHOOL}

At Hampton the chapel exercises were at night. Here they sang the beautiful old negro melodies and listened to a talk by General Armstrong, or some other good speaker. One Sunday night in May, I88I, after the regular exercises, General Armstrong, who had a way of taking the students into his confidence as well as keeping them informed of matters of interest to the race, announced that he had received a very interesting letter. He then told them that the Legislature of Alabama at its last session had set aside some money for the establishment of a negro normal school, and that they were looking for a man to be the head of this school and that he had been asked to recommend such a man. Of course they wanted a white man. However, the next day General Armstrong sent for Booker Washington and said: "Washington, you heard the announcement last night about the men in Alabama who want a man to be the head of their school. I have decided that you are the man for them. Will you take the place if it is offered to you?"

This was surely a great surprise, but Booker Washington was always ready. He said: "I think I can fill the place, and I am willing to try." 
General Armstrong wrote at once about Washington. The next Sunday night, during the chapel exercises, a telegram was handed to General Armstrong. It was from the committee in Alabama. He opened it, and read it to the audience. It said: "Booker Washington will suit us. Send him at once." 1

Washington prepared to go at once to his new field. After finishing his work at Hampton, he paid a visit to his old home at Malden, and a couple of weeks later, early in June, he arrived at Tuskegee, Alabama, to begin his new task.

Tuskegee at this time was a quiet little town of about two thousand inhabitants. It is on a small branch railroad, five miles from the main line, which runs from Atlanta, Georgia, to Montgomery, Alabama. The town is about fifty miles from Montgomery. It is right in the heart of what is known as the "Black Belt" in the South. A large and typical population lived round about. The town was the county seat of Macon County, in which lived a large number of negro farmers, all living very much as the negro family lived in the South at that time. The white people and the negroes were about equal in population in the town and lived in cordial and friendly relations.

Booker Washington had a great surprise awaiting him when he reached Tuskegee. He thought that this school that he was to be the head of was 1 "Up from Slavery," by Booker T. Washington, p. Io7. 
already in existence and naturally looked about to find the schoolhouse, of course expecting to see a nice building. Imagine his surprise when he found that there was as yet no school at all and absolutely no building, no sign of a school whatsoever. He was to start this school himself from the very beginning. The legislature had simply set aside two thousand dollars a year to be used only for paying salaries, and no provision had been made for building and grounds.

Was Booker Washington discouraged? Not for a single minute did he sit down and whine and complain and say that he might as well give up. He went right out into the town, looked up some of the leading men of both races, and told them that he was going to start something; that he was going to open a school. And the men, a little amazed at first, caught his enthusiasm and said: "Good for you. We are with you. You can count on us. We will help."

His first effort was to find a house to use as a school building, and he finally secured a little shanty that stood near the A. M. E. Church. It was agreed that he could use this building for meetings of any kind, and that he could teach in the shanty. After consulting again with his friends, he announced that on July 4, I88I, the Tuskegee Institute would open.

Now that he had a place in which to begin work, his next job was to get students for his school. 
He began to visit around in the country, making talks in the churcies at the regular service or at Sunday school and at preaching services in schoolhouses and other places. He visited in the homes of the people, and everywhere he told them of his school plans.

In this way he came to know the people just as they lived, and they learned how sympathetic Washington was, and how he was trying to help them. Most of those he visited he found living in one- or two-room houses, with fat pork and corn bread as their principal food. But they always treated him kindly and entertained him the best they could. One thing that distressed him was the discovery that many of these people had been persuaded to buy such things as costly sewing machines and organs, when they didn't have enough to eat and to wear. At one place where he took dinner there were four in the family, and when they sat down at the table, he found that there was but one fork for all five of them.

Their lives were filled with much drudgery and hard work and almost no opportunities for improvement. It was nearly impossible for them to make a living, much less save any money. Their schools, if they had any at all, had very short terms and were taught by teachers who knew very little more than the children. It was a discouraging situation to any one except a man like Booker Washington. "These are my people," 
he said. "They need help. They need education and the kind of education that will give them cleaner and happier homes, healthier bodies, better schools, and better life in every way. I am going to help them."

The school opened on July 4, I88I, with thirty students. Washington was the only teacher. A large number of students wanted to enter, but he decided not to admit any under fifteen years of age. Some of these students were boys, and some were girls; some were grown men and women. Most of them had been teachers. None of them was very well prepared, however, for they had been very poorly taught. But the teacher found all of them eager to learn and ready to work.

Soon there were more students calling for admission. Within six weeks there were fifty students. It was necessary to have a new teacher, and the person secured for this work was Olivia Davidson, who afterwards became Booker Washington's second wife.

She was a great help to him, and she agreed with him that they must do something for the students besides merely teaching them books. Washington says that they wanted to teach them how to be clean; how to take care of their teeth and clothing; what and how to eat; and how to make a living.

All these pupils lived on the farm, as did nearly 
all the people of the South. Washington wanted to so teach them that they would continue to live among their own people and their lives would be happier and better in every way. He did not want them to get a false idea about education. Many of them had the wrong impression already. They thought that getting an education consisted in reading big books and then of being able to earn a living without work. Both of these ideas were wrong. He wanted to teach them something that would make them useful and happy and prosperous on the land in their native state.

He certainly could not do this while teaching in a little old shanty with one room that was in such bad condition that one of the pupils had to hold an umbrella over the teacher when it rained. He had this same experience at his boarding house, where his landlady often held an umbrella over him while he ate his breakfast.

About three months after the opening of his school, a small farm about one mile from town was offered for sale. Washington went out and looked it over and came to the conclusion that it was just the place for the kind of school that he intended to build. But the price was $\$ 500$, and he didn't have a dollar. The owner said: "Pay me \$250 cash, and I will give you one year to pay the other." Washington borrowed $\$ 250$ and closed the deal.

He decided to move the school at once to the 
new home. On this farm were four buildings. The "big house" had been burned, but there was left standing a little cabin, formerly used as a dining room, an old kitchen, a stable, and a henhouse. Booker Washington and his growing school moved into these four buildings.

The buildings were thoroughly cleaned and worked over and put in as good condition as pos-

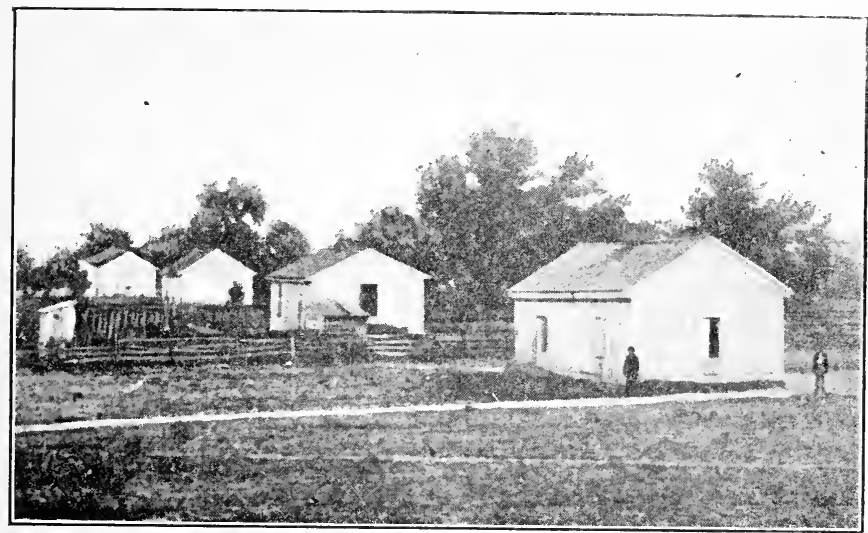

Tuskegee's First Group of Buildings

sible. Washington says, "I recall one morning, when I told an old colored man who lived near, and who sometimes helped me, that our school had grown so large that it would be necessary for us to use the henhouse for school purposes, and that I wanted him to help me give it a thorough cleaning out the next day, he replied, in a most earnest manner, 'What do you mean, boss? You 
sholy ain't going to clean out the henhouse in the daytime!"' 1

Do you know what a "chopping bee" is? Well, the students of Tuskegee didn't know until Booker Washington taught them. After they had been in their new quarters for several weeks, Washington walked in one day and said: "To-morrow we are going to have a 'chopping bee.' Now all of you that have an axe bring it to school with you. Those of you who do not have one, let me know, and I'll get one for you. We will dismiss school early and go to the 'bee.", 2

Next day everybody had an axe, and all of them were wondering what sort of game a "chopping bee" was. They had never been to one, and they were much excited over it.

Soon after dinner Washington got his axe and threw it on his shoulder and told the boys to come on. They eagerly followed. He led them out to the woods and began cutting down a tree, and told them to do the same thing. They did so. Washington, swinging his axe faster and better than any of them, led the crowd, though all of them were doing their best. And as they just kept on at this, it presently dawned on them that a "chopping bee," after all, was nothing but plain cutting down trees and clearing land. Some of

1 "Up from Slavery," by Booker T. Washington, p. I30.

2 "Booker T. Washington: Builder of a Civilization," by Scott and Stowe, p. 6. 
the students became angry. They said they did not come to school to do that kind of work; they came to study books. But they looked at Washington, who was an educated man, and they saw that he was not ashamed to do this kind of work. After a time they began to see what Washington's purpose was, and they quit complaining and gladly helped with all their might to get this needful work done.

There was another way in which Washington secured the assistance of others to build up his school. He had no way of going about over the country except by walking. He did not have a horse or a mule, and he could not cover much territory by walking. So he would watch for some old negro with a mule and wagon and go to him and tell him all about his plans. Then he would say: "Now, Uncle, don't you want to help in this good work? Well, come around early Saturday morning with your mule and wagon and take me out in the country, where I can see the people and tell them about our school," " and the old man would be there on time.

So, with the cordial coöperation of the students and friends in the town, the school was making progress. Land was being cleared, and the buildings and grounds were being improved. Washington was spreading the fame of his school through-

1 "Booker T. Washington: Builder of a Civilization," by Scott and Stowe, p. 7. 
out the country and every one was becoming interested.

But that debt of five hundred dollars for the land on which the school was being built had not been paid. Where was the money coming from? That was the hard question. Miss Davidson started the plan of having suppers or "festivals." She would go about town and get friends to donate a chicken or a cake or a pie for a supper. In this way a good sum was raised. Washington wrote to his friends, explained the situation, and asked for contributions. He asked the negroes as well as the white people in town to give, and they did. Washington says that sometimes they would give five cents, or twenty-five cents, or a quilt or some sugar cane. "I recall one old colored woman," he says, "who was about seventy years of age, she hobbled into the room where I was, leaning on a cane. She was clad in rags, but they were clean. She said: 'Mr. Washington, God knows I spent de bes' days of my life in slavery. God knows I's ignorant and poor; but I know what you and Miss Davidson is tryin' to do. I knows you is tryin' to make better men and women for de colored race. I ain't got no money, but I wants you to take dese six eggs, what I's been savin' up, and I wants you to put dese eggs into de eddication of dose boys and gals." " 1 Washington says that he has received many gifts for Tuskegee,

1 "Up from Slavery," by Booker T. Washington, p. I32. 
but none that affected him more deeply than this one.

Needless to say, by the end of the year the five hundred dollars had been raised and the debt paid.

Thus ended the first year of the history of Tuskegee. If you go there now and see the many fine buildings, the broad acres, the hundreds of students, and everything that goes to make up a great and wonderful college, it would be very hard to realize that it started off with one little shanty with a leaky roof, one teacher, and thirty students. From this simple and humble, but very earnest beginning, Tuskegee grew by leaps and bounds until it came to be the most remarkable negro school in the South. 


\section{CHAPTER VIII}

\section{STRENUOUS DAYS}

As Booker Washington began the second year of his school, he met a new obstacle. That was nothing unusual for him, however. He was usually facing a hard job. He spent his life working on difficult tasks, and he never found one that he did not finish with satisfaction. He tackled this problem at once and with confidence.

There were two parts to it. In the first place, although he had a fine farm of five hundred acres all paid for, he had no buildings, except that old kitchen, stable, and henhouse, in which to house his students. When school opened in the fall of I 882, there were about one hundred and fifty students present. These three or four little old shacks would not take care of that crowd. What was he to do? This was his first difficulty.

His other problem was this. His school was just outside the town of Tuskegee. It adjoined the town. A great many people in Tuskegee thought that this school ought not to be built. Many were opposed to Booker Washington. Many were opposed to educating negroes, and they believed that negroes went to school simply to get out of work, and that an educated negro was 
"sorry" and troublesome. Then there were some who said: "This man means well, but he is just a negro, and, of course, he can't succeed." Then, there were others who said: "This man Washington is all right. I believe in him and trust him. He is doing a good thing. He is going to succeed. I am counting on him." So, his second job was to win the friendship and good will of all the people in the town and round about and not to disappoint those who believed in him. He worked out these two problems together, as we shall see from what happened.

The very first thing needed by the students after all was not a building but something to eat. So the first move Washington made was to start the students to work on the farm in raising a crop. Every day, after the students had studied and recited their lessons, they would go to the fields and work. We have already learned how they found out what a "chopping bee" was. Now they were working in the fields where they had previously cut down the trees. Some of them did not like this work at first. They said: "We did not come to school to do work like this. We have had enough of this at home." But Washington kept right on, working hard himself and showing his students that he was not ashamed to do hard work with his hands.

The next thing in order was a building - a good building, large and comfortable and useful. 


\section{$5^{8}$ BOOKER T. WASHINGTON}

He began to make plans for it. He knew he had to have it, and, although he really did not have any money at all in hand, he went right ahead and planned a fine building to cost six thousand dollars. He did not know where he would get the

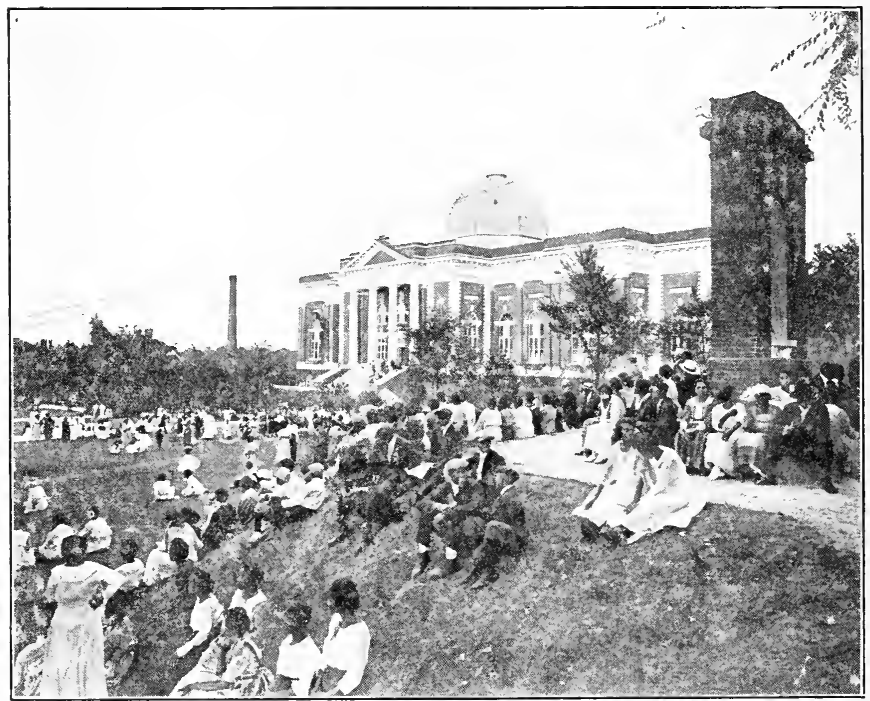

A Sunday Afternoon Band Concert on the Campus

money, but he had a firm belief that in some way the money would be secured.

When it was learned that he expected to put up this building, a man who lived near Tuskegee and who owned a sawmill came to Washington and said to him: "I have been watching you. I know what kind of a man you are. You will keep 
your word, and you will pay your debts. I see that you need some help. I just want to say that I will furnish you all the lumber you need for this building at once, and you can pay just whenever you are able." Washington explained that, while he hoped to be able to raise the money to pay for the building, he had not yet secured any of it. The man replied: "That's all right. Your credit is good with me; I will trust you."

We can see from this incident how well he was succeeding in making friends with his neighbors.

As soon as he had raised a part of the money, he let the man put the material on the ground. Then the building was begun, and again the students did all the work. They first digged the foundations, and some of them became so disgusted with this work that they left the place altogether. Washington was sorry that they left, but he said that any one who was too proud to work with his hands and help out at a time like this did not belong in his school. However, most of the students remained and were perfectly willing to do the work. Rapid progress was made, the foundations were finished, and they were ready for the laying of the corner stone.

The laying of the corner stone of this building is an important event in the history of the education of the negro. There was a great crowd present. Washington, his teachers, his students and their parents, and a large number of other 
negroes were there. There were present, also, a large number of white people, - the mayor of the town, the councilmen, the sheriff and all the other county officers, and all the prominent business and professional men of the community.

In a way this ceremony marks an epoch in Negro history in America. Just seventeen years before, it was against the law for a negro to be taught books at all in Alabama. Just seventeen years before, the negroes were slaves, - for this was in 1882 and in the "Black Belt," in the very heart of the South. That this large group of white men should gather with the negroes for the purpose of dedicating a building to negro education shows what wonderful change of sentiment had taken place. It shows also how thoroughly Booker Washington had won the confidence of all the people among whom he was working.

All his students were from Alabama. Most of them were from the country. He knew that most of them would spend their lives on the farm or in occupations of some kind. He wanted them to be practical; to know how to do well the things they would surely be compelled to do. So he determined from the very beginning that his students should learn how to do practical things as well as learn from books. He had them c ear the land for the school; he had them farm the cleared lands; he had them do the cooking; he had them make the brick and build the buildings of the school. He 


\section{STRENUOUS DAYS}

says that his idea was to teach the students the best methods of labor and how to derive the greatest benefit from their work. He wanted them to learn new ways of work, - how to use steam, water, and electricity. He also wanted to teach them that work was dignified and honorable and

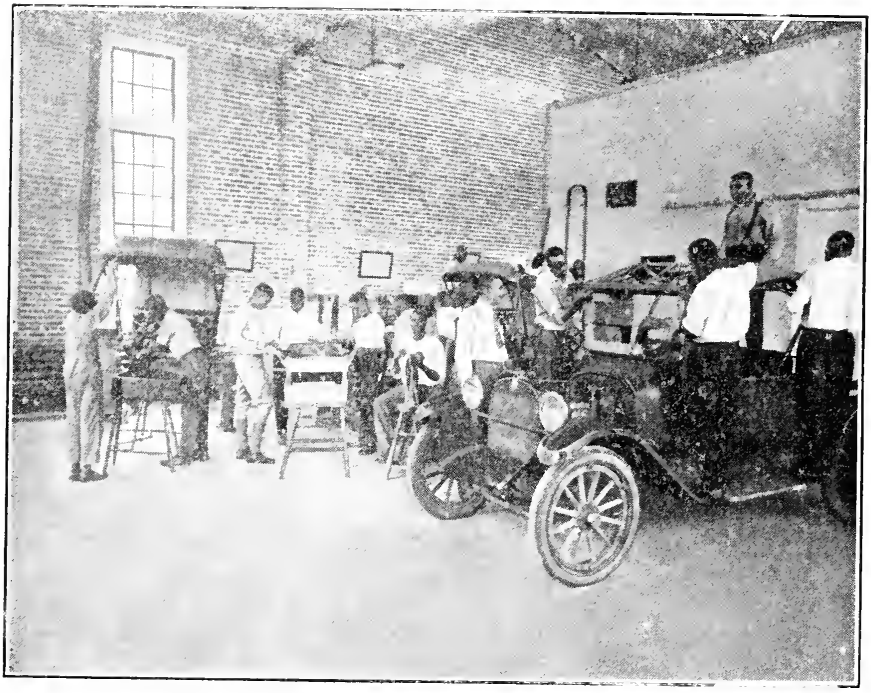

Automobile And Buggy Trimming at Tuskegee

that nio man should be ashamed to do any kind of honest work.

He followed this plan till his death, and nearly every one of the many buildings that stood at Tuskegee when he died was built entirely by the students themselves.

They planned to build this first large building - 
"Porter Hall" they called it - of brick; so they went out to make the brick right there. The students did not like this work. It was hard and it was dirty. However, they went at it and, after several trials, found some brick clay.

They molded the brick, built the kiln, fired it, and waited. When the burning was done, they found that they had made a complete failure. None of the brick could be used. At once they built another kiln. This also turned out to be a failure. Some of them were discouraged at this, and said: "Let's quit." But others said: "We must succeed." So a third kiln was built. This kiln seemed to be burning splendidly when suddenly, on the last night, it fell.

This was surely discouraging, but Washington was not to be stopped by failure. He was now without a dollar to continue this work. He happened to think, however, of a watch he owned. He took the watch to Montgomery, Alabama, near by, pawned it for fifteen dollars, came home, called the workers together once more, built another kiln, and this time the kiln was a success.

Later, when he went back to get his watch, it was gone; but he never regretted losing it in such a good cause.

Now that he was successful in making bricks, the work progressed on the buildings, and soon Porter Hall was finished, and other buildings were started. 


\section{STRENUOUS DAYS}

There were two other things Washington wanted for his school. One was a place for his students to board, and the other, a place for them to room. Washington said that he had nothing but the students and their appetites to begin a boarding department with. However, they got busy, dug a large amount of earth from beneath Porter Hall, and opened this basement up for a dining room. They had no dishes, no knives and forks to speak of, at first; they had poor arrangements of every kind. And they had bad luck. Something went wrong almost every day at first. They would spill the soup, burn the meat, or leave the salt out of the bread. Meals were served with no sort of regularity.

Washington says that one morning he was at the dining room when everything went wrong. The breakfast was a failure. One of the girls who failed to get any breakfast went to the well to get a drink of water, and found the well rope broken. Washington heard her say: "You can't even get water to drink at this school." " He says that remark came nearer discouraging him than anything that ever happened to him.

He may have been discouraged, but he kept on, and in a little while things were coming out all right. And to-day, one of the greatest sights at Tuskegee is the great dining hall with its white tablecloths, napkins, and vases of flowers, with

1 "Up from Slavery," by Booker T. Washington, p. I6I. 


\section{4}

BOOKER T. WASHINGTON

elegant meals served in excellent style and order and on time.

The next thing was rooms for the boarders. Students were coming from a distance. There was no place for them at the school. Besides, Washington wanted them at the school so that he could help them learn best how to keep their rooms and live as folks ought to live. They used the cabins first for sleeping quarters, but they had almost no furniture. They made mattresses of pine needles. Their bedclothes were so scant the first winter that several were frostbitten.

Soon a good house was built, however, for all the students, and now they began to live as people ought. Among other things, Washington insisted that they use toothbrushes. He said that perhaps no one thing meant more in the real training of the negro than the proper use of this article. He went from room to room himself to see whether the students had them. "We found one room," he says, "that contained three girls who had recently arrived at the school. When I asked them if they had toothbrushes, one of the girls replied, pointing to a brush, 'Yes, sir, that is our brush. We bought it together yesterday.' It did not take them long to learn a different lesson." 1

In many ways, he was able to help these students learn the proper ways of living - how to sleep I "Up from Slavery," by Booker T. Washington, p. 175 . 


\section{STRENUOUS DAYS}

properly, how to care for their bodies, and how to take care of their clothes.

This second year of the school was truly a strenuous one in clearing land, raising a crop, making bricks, building Porter Hall, starting a boarding department and a rooming department.

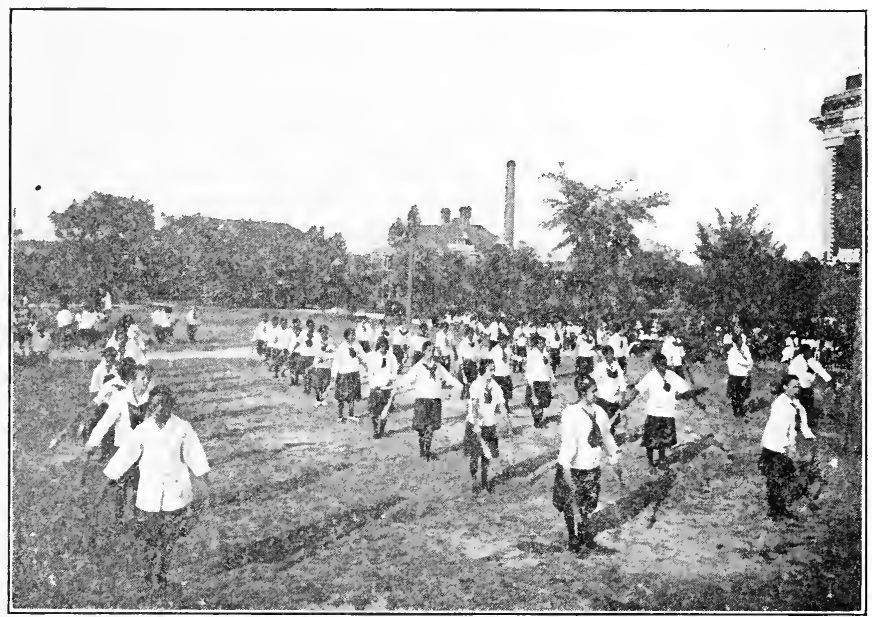

Class in Physical Training at Tuskegee

Everybody had been busy doing good work, and everybody was happy. They were making a great beginning.

A very important event of this year was the marriage of Washington to Fannie M. Smith. They had known each other back in Malden, and, as soon as Washington's work was well begun, they were married. She lived only two years after 
her marrage, dying in I884, and leaving a daughter, Portia M. Washington. Several years later Washington married Olivia Davidson, the teacher who had been associated with him in the school almost from the first, and who had done so much to help him in getting the school started. 


\section{CHAPTER IX}

\section{RAISING MONEY FOR TUSKEGEE}

TUskegeE grew rapidly and steadily. Students began to pour in from all parts of the country. Girls were coming as well as boys. It was absolutely necessary to find some place for these students to live and carry on their school work. Tuskegee Institute had no money. You will remember that the Legislature of Alabama appropriated two thousand dollars a year for the payment of teachers, but gave nothing for buildings or land or equipment. So if new buildings were to be erected, it meant that the money would have to be raised by some other means. This was not a church school, and it could not, therefore, appeal to any religious denomination for help. There was only one way to secure funds for its development and growth and that was by going out and asking people directly for aid.

Washington did not like to do this, but, recognizing the necessity for it, he went bravely ahead. And perhaps no man was ever more successful in this work than he was. President Charles W. Eliot, of Harvard University, had to raise money in the same way for Harvard. He was so successful that it was said of him, "When he goes to rich men they just throw up their hands and say, 
'Don't shoot! How much do you want?'” And President Eliot said that Washington could beat him raising money.

Before Washington's death in 1915 , it required from $\$ 250,000$ to $\$ 300,000$ a year to run Tuskegee. That is a big sum of money. A very large part of it had to be raised by personal solicitation. And it had to be raised almost entirely in the North. This meant that Washington had to spend a large part of his time away from Tuskegee, traveling over the country, making speeches, and talking to individual men. It was hard work, and it took a great deal of strength and effort as well as time. He had many remarkable experiences. He met many great and good people, who were glad to help him. He had an opportunity to tell them about his school and about his people in the South; and an opportunity to hear this remarkable man was given to many people.

This is the way he was led to undertake this work. When the girls began coming to school, they had to have a dormitory. The boys had been staying in the attic of Porter Hall, living in the shanty, or boarding in town. But this would not do for the girls. They must have different accommodations. The boys ought to have, but the girls must have better surroundings. So they proceeded to plan a dormitory. They did not have any money with which to build a house. It was just like starting Porter Hall. But they said they 


\section{RAISING MONEY}

could at least plan the kind of building they would build if they had the money. They made plans for a building that would cost ten thousand dollars, and named it Alabama Hall. But that Alabama Hall was on paper only and in the minds of folks; so they could not use it very well.

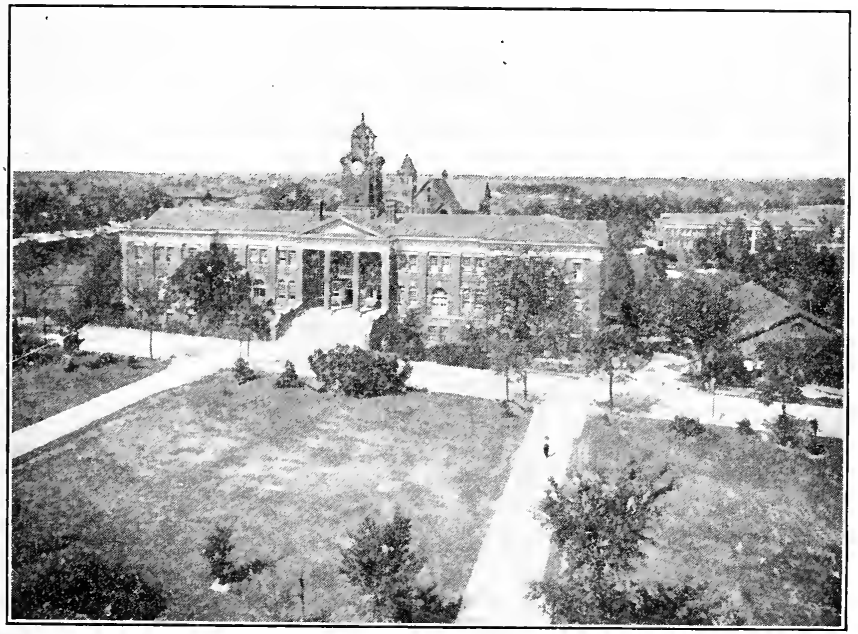

White Hall (Girls' dormitory), Chapel (rear), Tatum Hall (right), Tuskegee Institute

Then an interesting thing happened. Have you noticed how often something interesting turned up with Washington? Perhaps there is a good reason for it. "Nothing ever comes to one, that is worth having, except as a result of hard work," Washington himself has said. It was not just an accident after all that these good things 
were happening. It was because Washington by his work and his good sense had made lasting impressions upon people who were in positions to give him help.

This is what happened. While thinking about how he could get the ten thousand dollars for Alabama Hall, he received a letter from General Armstrong, asking if he would agree to go with him on a tour of the North; if so, to come to Hampton at once. Washington was delighted and accepted the invitation. To his great surprise he found that General Armstrong had planned to take a quartette of singers from Hampton and go himself with Washington on a tour of the North in the interests of Tuskegee. Washington thought the trip was planned for Hampton, of course, and, when he found that General Armstrong had been so unselfish as to plan it for him, he was overcome with gratitude.

They had a great trip. General Armstrong had Washington do most of the speaking. "Give them an idea for every word," he said to Washington as they started. And Washington did. It was on this trip that Washington first introduced Tuskegee to the people of the North, and that the people first got acquainted with Washington. When he returned from this trip, he was able to begin work on Alabama Hall, and it was soon completed and paid for. From this time on Washington went North a great deal to speak 
publicly and to talk privately to men about the needs of Tuskegee.

He met a great many rich men. He had many interesting experiences with them. He did not "beg" from them. He says he always followed two simple rules in this work: first, to do his full duty in presenting the needs of the school, and, second, not to worry about the results. He found these rich men unlike what he had expected. He said they were among the best and kindest and most generous people in the world. While he sometimes received discourteous treatment, as a rule he was gladly received and treated with great respect, and help was gladly given.

Three of the rich men who helped Washington a great deal were: Collis P. Huntington, the great railroad builder; $H$. $H$. Rogers, of the Standard Oil Company, and Andrew Carnegie, the philanthropist, who had made a fortune in the steel industry. Washington says that the first time he interviewed Mr. Huntington he received a donation of two dollars. Two dollars from a multimillionaire! But the last donation he received from Mr. Huntington was a check for fifty thousand dollars. And between the two gifts there had been gifts of many thousands. Mr. Rogers also gave many thousands of dollars and helped particularly in the great extension work of the college.

The most liberal giver was Andrew Carnegic. As soon as Carnegie heard of the work that Wash- 
ington was doing, he sent for him to come to New York City. The result was that Carnegie gave him fifteen thousand dollars with which to build a library. Washington and his coworkers spent a great deal of time working out the plans for this building. All the work was done by the students

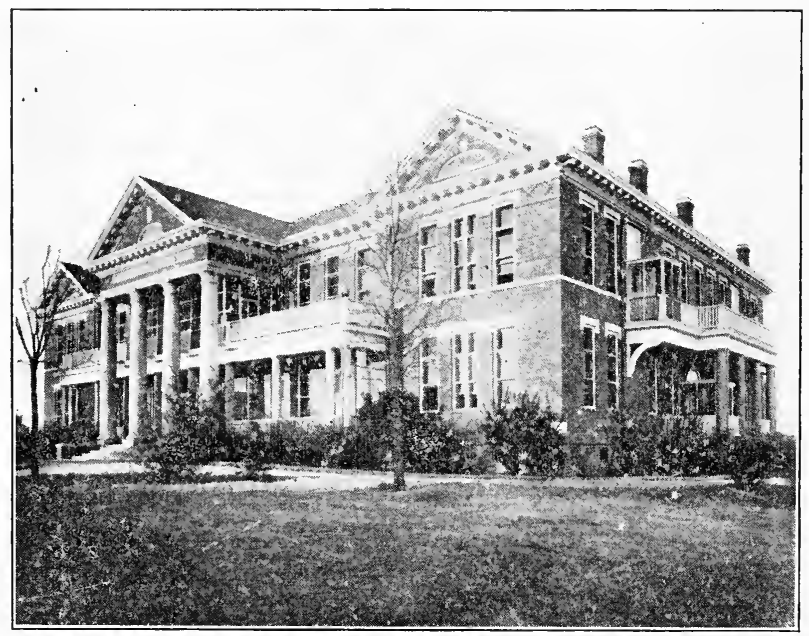

John A. Andrew Memorial Hospital, Tuskegee Institute

of Tuskegee. When it was completed, Carnegie was amazed that such a beautiful and useful building had been built for that sum of money. It convinced him that these people could be trusted to spend money wisely. He therefore determined to give a large sum to the school. Thus it happened, in 1903, that the President of the Board of Trustees of Tuskegee received the following letter: 
New York, April i 7, igo3.

My dear Mr. Baldwin:

I have instructed Mr. Franks, Secretary, to deliver to you as Trustee of Tuskegee $\$ 600,000$ of 5 per cent U. S. Steel Co. bonds to complete the Endowment Fund as per circular.

One condition only - the revenue of one hundred and fifty thousand of these bonds is to be subject to Booker Washington's order to be used by him first for his wants, and those of his family during his life or the life of his widow. If any surplus is left he can use it for Tuskegee. I wish that great and good man to be free from pecuniary cares that he may devote himself wholly to his great mission.

To me he seems one of the foremost of living men, because his work is unique, - the Modern Moses, who leads his race and lifts it through Education to ever better and higher things than a land overflowing with milk and honey. History is to know two Washingtons, - - one white, the other black, both fathers of their people. I am satisfied that the serious race question of the South is to be solved wisely only by following Booker Washington's policy, which he seems to have been especially born - a slave among slaves - to establish, and, even in his own day, greatly to advance.

So glad to be able to assist this good work in which you and others are engaged.

$$
\begin{gathered}
\text { Yours truly, } \\
\text { (Signed) Andrew Carnegie. }
\end{gathered}
$$

To Mr. William H. Baldwin, Jr., New York City, N. Y. ${ }^{1}$

1 "Booker T. Washington: Builder of a Civilization," by Scott and Stowe, pp. 258-259. 


\section{$7+$ BOOKER T. WASHINGTON}

One other name must be mentioned, and that is Julius Rosenwald of Chicago. Mr. Rosenwald not only gave large sums himself - and is still giving enormous amounts not only to Tuskegee but to the cause of negro education throughout the South - but frequently left his own business

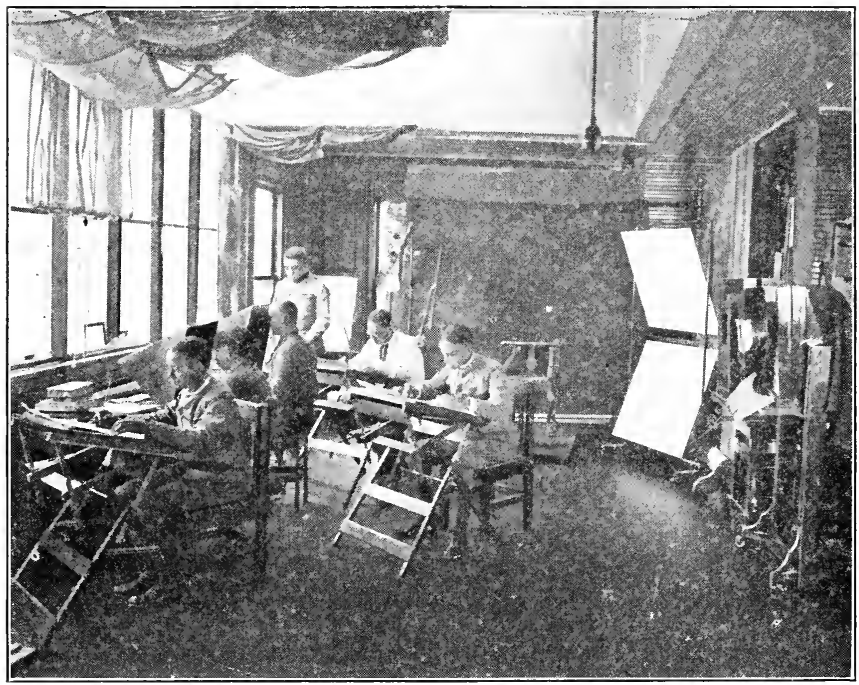

Class in Photography, Tuskegee Institute

and helped to raise money among his friends for Tuskegee.

There were many large gifts from many men and women, all of whom cannot be mentioned here of course, but most of the money that was given to Tuskegee came in small amounts from a large number of people, - from churches, Sunday 


\section{RAISING MONEY}

schools, miss:onary societies, and other organizations; from preachers, teachers, lawyers, doctors, farmers - from every class of people came gifts, sometimes large and sometimes small. All the graduates of Tuskegee were loyal and gave something, however small the amount might be The Alabama Legislature gave more and more as the school grew. The Slater Fund and the Peabody Fund also began to make annual contributions to the school.

It was through all these channels that the money came pouring 'nto Tuskegee in such amounts that it was poss ble for it to grow and develop in a remarkable way. Building after building went up. New students came. New equipment was purchased. Additional faculty members were secured. And the school grew in size and usefulness and in favor in the eyes of the people. 


\section{CHAPTER $\mathrm{X}$}

\section{MAKING SPEECHES}

Frederick Douglass and Booker Washington rank as the greatest orators the negro race has ever produced. This is a high place to occupy, for the race has produced many remarkable speakers.

Douglass was the great spokesman for the race just before the Civil War and during the troublesome days of reconstruction. Washington began his career just at the time that Douglass ended his. Douglass was a very eloquent man; perhaps more eloquent at times than Washington. On the other hand, Washington was a better educated man than Douglass and probably had a more lasting influence upon his generation.

Booker Washington made thousands of speeches in his life. He spoke to white and black; in the North and in the South; in Europe as well as in America. He spoke in churches; at school commencements; at conventions; at educational and religious meetings; at county fairs; and to every kind and condition of people. He spoke before lings and presidents; he spoke to the lowliest men of his own race in the heart of the black be.t in Alabama. It is a wonderful thing to be an 
orator; to speak to men and women in such a way that they will be helped and inspired and made happier and more useful.

When Washington was at Hampton, he began to learn the art of speaking. You remember how he organized a debating society which met for the twenty minutes they had between supper and time to begin work. You remember how he spoke and spoke at these meetings, doing his best to learn how to express himself well. One of his teachers, Miss Mackie, knew of his ambition to become a good speaker, and she gave him a great deal of help, teaching him how to stand, how to pronounce his words, and how to control his voice and gestures. By much hard work he came to be the best speaker among the boys at Hampton.

You will recall, too, how General Armstrong invited him to deliver the alumni address in 1879 , and what a big success he made of that. All this time he was speaking at Sunday schools, at churches, at educational meetings, and everywhere he had an opportunity. His trip North with General Armstrong gave him much valuable experience.

The first speech that he made that attracted the attention of all the people was at the National Education Association, in Madison, Wis. The most important thing he said in this speech was that the "whole future of the negro rested largely upon the question as to whether or not he should 
make himself, through his skill, intelligence, and character, of such undeniable value to the community in which he lived that the community could not dispense with his presence." He said that any one who "learned to do something better than anybody else - learned to do a common thing in an uncommon manner - had solved his problem, regardless of the color of his skin." $1 \mathrm{He}$ also said that the two races ought to be brought closer together and cultivate the most cordial and friendly relations, rather than become bitter toward each other.

But the greatest speech of Washington's life was the Atlanta speech. In the year I 895 the people of Georgia determined to hold a great Cotton States Exposition, in Atlanta, which would set forth the progress of the South since the Civil War. In order to make the exposition a great success it was necessary to have the financial assistance of Congress. So a committee was appointed to go to Washington to confer with a committee from Congress. Booker Washington was appointed on this Georgia committee; and his speech in Washington before the Congressional committee was one of unusual force. Many said it was the best speech made. Congress gave the assistance asked.

When the authorities came to plan the exposition in detail, they decided to have a Negro

1 "Up from Slavery," by Booker T. Washington, p. 202. 
Division. The negroes were asked to take part, and they gladly agreed to do so They built one of the best buildings on the grounds. This building was planned by a negro architect and was erected entirely by negro labor. It contained exhibits prepared altogether by negroes. It was one of the most interesting parts of the entire exposition.

When the exposition was formally opened in September, I 895, Booker Washington was invited to make an address as a representative of the negro race. James Creelman, a noted newspaper man, the correspondent of the New York World, heard that speech, and he wrote to the World about it. This is what he wrote:

"Mrs. Thompson, one of the other speakers on the program, had hardly taken her seat, when all eyes were turned on a tall, tawny negro, sitting in the front row of the platform. It was Professor Booker T. Washington, President of the Tuskegee (Alabama) Normal and Industrial Institute, who must rank from this time forth as the foremost man of his race in America. Gilmore's Band played the 'Starspangled Banner,' and the audience cheered. The tune changed to 'Dixie' and the audience roared with shrill 'hi-yi's.' Again the music changed, this time to 'Yankee Doodle,' and the clamor lessened.

"All this time the eyes of the thousands present looked straight at the negro orator. A strange thing was to happen. A black man was to speak for his people, with none to interrupt him. As Professor Washington strode to the edge of the stage, the low, descending sun shot fiery rays through the windows into his face. A great shout greeted him. He turned his head to avoid the blinding light, and moved about 
the platform for relief. Then he turned his wonderful countenance to the sun without a blink of the eyelids, and began to talk.

"There was a remarkable figure; tall, bony, straight as a Sioux chief, high forehead, straight nose, heavy jaws, and strong, determined mouth, with big white teeth, piercing eyes, and a commanding manner. The sinews stood out on his bronzed neck, and his muscular right arm swung high in the air, with a lead pencil grasped in the clinched brown fist. His big feet were planted squarely, with the heels together and the toes turned out. His voice rang out clear and true, and he paused impressively as he made each point. Within ten minutes the multitude was in an uproar of enthusiasm - handkerchiefs were waved, canes were flourished, hats were tossed in the air. The fairest women of Georgia stood up and cheered. It was as if the orator had bewitched them.

"And when he held his dusky hand high above his head, with the fingers stretched wide apart, and said to the white people of the South, on behalf of his race, 'In all things that are purely social we can be as separate as the fingers, yet one as the hand in all things essential to mutual progress,' the great wave of sound dashed itself against the walls, and the whole audience was on its feet in a delir um of applause.

"I have heard the great orators of many countries, but not even Gladstone himself could have pleaded a cause with more consummate power than did this angular negro, standing in a nimbus of sunshine, surrounded by the men who once fought to keep his race in bondage. The roar might swell ever so high, but the expression of his earnest face never changed.

"A ragged, ebony giant, squatted on the floor in one of the aisles, watched the orator with burning eyes and tremulous face until the supreme burst of applause came, and then 
the tears ran down his face. Most of the negroes in the audience were crying, perhaps without knowing just why.

"At the close of the speech Governor Bulloch rushed across the stage and seized the orator's hand. Another shout greeted this demonstration, and for a few minutes the two men stood facing each other, hand in hand." 1

It was a wonderful speech. It contained much good advice both to the whites and to the negroes. It was fair to both. As Clark Howell, editor of the Atlanta Constitution, said, "It was a platform upon which both races, black and white, could stand with full justice to each other." 2 In the speech he told the following story: "A ship lost at sea for many days suddenly sighted a friendly vessel. From the mast of the unfortunate vessel was seen a signal: 'Water, water; we die of thirst.' The answer from the friendly vessel at once came back, 'Cast down your buckets where you are.' A second time the signal, 'Water, water, send us water,' ran up from the distressed vessel, and was answered, 'Cast down your buckets where you are.' And a third and a fourth signal for water was answered, 'Cast down your buckets where you are.' The captain of the distressed vessel, at last heeding the injunction, cast down his bucket, and it came up full of fresh, sparkling water from the mouth of the Amazon River." Washington then appealed to his own people to

1 "Up from Slavery," by Booker T. Washington, pp. 239-240.

${ }^{2}$ Ibid., p. 226. 
"cast down their buckets where they were," by making friends with their white neighbors in every manly way, by training themselves where they were in agriculture, in mechanics, in commerce, instead of trying to better their condition by immigration. And, finally, to the white Southern people, he appealed to "cast down their buckets where they were," by using and training the negroes whom they knew rather than seeking to import laborers whom they did not know. ${ }^{1}$

Frederick Douglass had died only a few months before this great speech was made. At once from all parts of the country came the statement, "Here is the man who will take the place of Douglass as leader of the negro race." And from that time on, Booker Washington was the accepted leader of his people in this country.

He was immediately called upon to speak in all parts of the country. He was offered big sums of money to lecture. One speaker's bureau offered him fifty thousand dollars a year. He refused all these offers of money, saying that he must give his time to Tuskegee and to the interests of his people, rather than try to make money for himself. Another of his great speeches was made at Cambridge, Mass., in 1896 . Harvard University, the oldest and most famous university in America, conferred the honorary degree of master of arts upon Mr. Washington in 1896 . This was the

1 "Up from Slavery," by Booker T. Washington, p. 219. 
first time in the history of America that a college or university of such high standing had ever conferred an honorary degree upon a negro. Wash ngton says this honor was the greatest surprise of his life. At the time the ceremony of conferring this degree took place, he made a speech that won great applause from the audience.

It is very interesting to read Washington's own account of his experiences. "People often ask me," he says, "if I feel nervous before speaking, or else suggest that, since I speak so o ten, they suppose I get used to it. In answer to this question I have to say that I always suffer intensely from nervousness before speaking. More than once, just before I was to make an impor ant address, this nervous strain has been so great that I have resolved never again to speak in public. I not only feel nervous before speaking, but after I have finished I usually feel a sense of regret, because it seems to me as if I had left out of my address the best thing that I had meant to say. . . Nothing tends to throw me off my balance so quickly, when I am speaking, as to have some one leave the room. To prevent this, I make up my mind, as a rule, that I will try to make my address so interesting, will try to state so many interest ng facts one after another, that no one will leave." 1

Washington made it a rule never to say anything to a Northern audience that he would not

1 "Up from Slavery," by Booker T. Washington, pp. 242, 244. 
say to a Southern audience. He also made it a rule never to say to a negro audience anything that he would not say to a white audience. In this honest and fair way he kept close to the truth, and at the same time never offended fairminded people of either race.

He was a capital story-teller, but he did not make a practice of telling jokes and funny stories in his speeches, just to make people laugh. He always had a serious purpose in his stories. $\mathrm{He}$ had two or three stories that he told frequently, because they were so full of meaning. This was one of them: One day he was going along the road, and he met old Aunt Caroline, with a basket on her head. He said, "Good morning, Aunt Caroline. Where are you going this morning?" And she replied, "Lor' bless yer, Mister Washington, I dun bin where I's er goin." "And so," he would then say, "some of the races of the earth have done been where they was er goin'. But the negro race is not one of them. Its future lies before it." 1

Another of his stories was about a good old negro who accompanied Washington on one of his tours. At a certain city they found that they had several hours before the train left; so this old man decided to stroll about to see the town. Presently, he looked at his watch and found that

1 "Booker T. Washington: Builder of a Civilization," by Scott and Stowe, p. 30. 
it was just about time for his train to leave, and he was some distance from the station. He rushed to a hack stand, and called out to the first driver he came to, who happened to be a white man, "Hurry up, and take me to the station; I's gotta get the 4:32 train." 'To which the white driver replied, "I ain't never drove a nigger in my hack yit, an' I ain't goin' ter begin now. You can git a nigger driver ter take ye down." 1

To this the old colored man replied with perfect good nature, "All right, my friend, we won't have no misunderstanding or trouble; I'll tell you how we will settle it; you jest hop in on der back seat an' do der ridin' an' I'11 set in front an' do der drivin'." In this way they reached the station on good terms, and the old man caught his train. Like this old negro, Washington always devoted his energies to catching the train, and it made little difference to him whether he sat on the front or back seat.

Two other speeches of Washington attracted wide attention. One of these was delivered in Boston in $\mathbf{I} 897$, at the time of the dedication of a monument to Robert Gould Shaw. Shaw was the Colonel of the famous negro regiment of soldiers from Massachusetts in the Civil War. It was in this regiment that Sergeant William H. Carney served, - the man who triumphantly carried the

1 "Booker T. Washington: Builder of a Civilization," by Scott and Stowe, pp. 30-3I. 
flag in the great battle of Fort Wagner, and exclaimed after the fight, "The o'd flag never touched the ground!" Colonel Shaw lost his life in the battle of Fort Wagner, whi'e leading his negro regiment. The people of Boston erected a monument to his memory, and Washington's speech at its dedication was one of the greatest he ever made.

One other speech was delivered in Chicago in I 898 at a great Peace Celebration, following the close of the Spanish-American War. There was an enormous crowd - the largest he ever spoke to, Washington says. There were sixteen thousand people present. President McKinley was there, together with several cabinet members and other distinguished guests. "The President was sitting in a box at the right of the stage," says Washington. "When I addressed him I turned to the box, and as I finished the sentence thanking him for his generosity, the whole audience rose and cheered again and again, waving hats and handkerchiefs and canes, until the President arose in the box, and bowed his acknowledgments. At that the enthusiasm broke out again, and the demonstration was almost indescribable." 1

The demands for him to speak were so great that it was impossible for him to meet them all. He often spoke three and four times a day. He was away from Tuskegee, making speeches, a large part of his time. He made extended tours, 1 "Up from Slavery," by Booker T. Washington, p. 255. 
by special train, all over the states of Virginia, North Carolina, Georgia, Alabama, Arkansas, Louisiana, Mississippi, and Tennessee. On these tours he spoke to thousands and thousands of people. Everywhere he went all the people, white and black, heard him gladly. The good that this man did through his oratory cannot be overestimated. 


\section{CHAPTER XI}

\section{SUCCESS AS EDUCATIONAL LEADER}

Booker Washington spent his life in the education of the negro. Negroes of ability in his day usually became preachers or they entered politics. The negro preacher had rendered a greater service to his people, perhaps, than any one else. Before I 865 , the ministry was practically the only place where negro leadership could find expression. It was much the same way for many years after the Civil War. However, after emancipation, there was an opportunity for leadership in politics, and a great many negroes of ability entered this field, many of them holding offices.

Washington was urged by some of his friends to enter the ministry. Others urged him to study law and enter politics. Undoubtedly he could have made a great success in either of these fields of work. But from the very beginning of his education, he had a strong conviction that his life must be spent in helping to educate his people.

He felt that education was the greatest need of his race. Before the war, it had been against the law for a slave to be taught from books. At the close of the war, then, there were no schools, no teachers, and no books. The whole race could 
neither read nor write. The whole race had had no training of any kind except in agriculture. It is true a few, but a very few, had had a little training in certain trades such as bricklaying, blacksmithing, and carpentry. The race, therefore, through no fault of its own, was very ignorant. It had never had an opportunity.

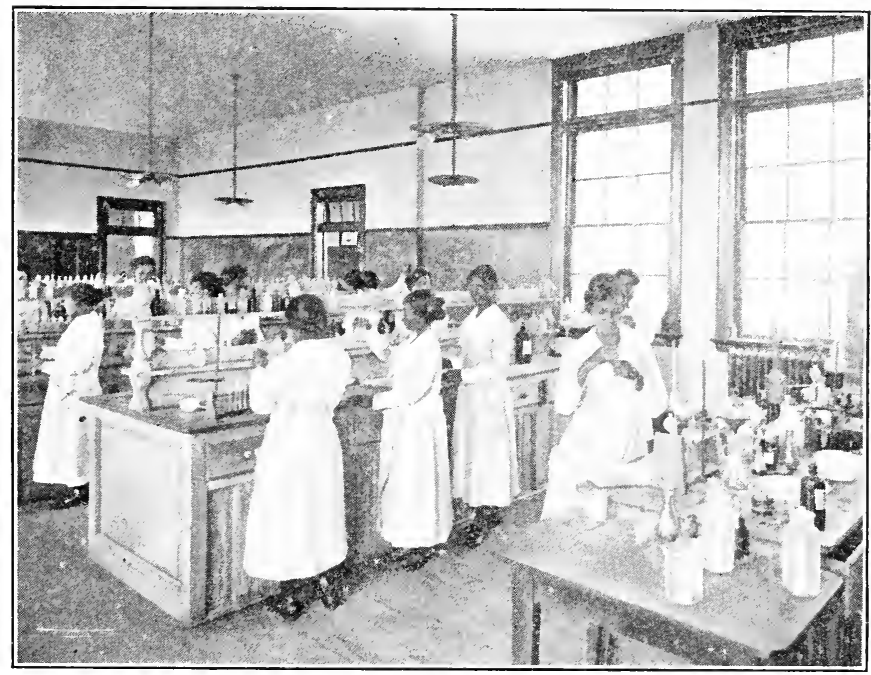

Chemistry Class, Tiskegee ACademic Department

But now that the opportunity had come with emancipation, the entire race was eager to learn. Old men and old women, as well as boys and girls, began with great zeal to learn to read and write. The race started to school. It was determined to get an education, and it was to help in this great 
work that Washington eariy determ ned to devote his life.

Just after the war there was much confusion and doubt about the best plan to follow in educating the negro. The Freedmen's Bureau brought a large number of teachers from the North to assist in the task, and much valuable work was done in the negro schools by these teachers. The d fferent Southern states also began to make provision for the negro's education, by organizing schools, building schoolhouses, and making provision for training teachers.

There was much difference of opinion as to just what should be taught the negro. As a rule, the plan followed was to teach him just what had been taught in the white schools. This meant that he would study reading, writing, arithmetic and grammar, and later, Latin, Greek, mathematics and literature.

So much of this kind of teaching was done, and it was so poorly done, and it was so poorly adapted to the needs of the negro at the time, that a great many people began to doubt the wisdom of trying to educate the negro at all. But Washington insisted that the mistake was made in the kind of education they were trying to give him. In answer to the question, "Does it pay to educate the negro?" Washington often told the story of what had taken place in Macon County, Alabama, the county in which Tuskegee is located. In that 
county, he and Mr. H. H. Rogers decided to build, with the coöperation of the people themselves, a system of excellent schools, and try out as thoroughly as possible the question of the effect of education upon the negro, under favorable conditions. They put up good schoolhouses, secured good teachers, taught practical subjects, and ran the schools for eight or nine months in the year.

What was the result? In a short time people began to come from all parts of the state and outside the state to buy land or to work within reach of these excellent schools. Land advanced in price. Desirable citizens flocked in. Homes were improved. Good roads were built. Better farms appeared. Crime diminished. The sheriff said that he practically had no further use for the jail. Cordial relations existed between the white and negro people. In every way Macon County came to be a better place to live in. The race problem was solved in that county. People were happy and prosperous. They were living clean, wholesome, contented lives. The whole problem of living was, in a large measure, solved. And it was all due to education of the people, and education of the right kind. What was good for Macon County, Alabama, would be good for every county in the country.

Washington's ideas of education were very simple. He had studied carefully the needs of his people. What he wanted was a system of educa- 
tion that would help people directly and immediately; that would enable them to make better crops; build better homes; wear better clothes; eat better food; live cleaner and purer and happier lives. He wanted his people to learn to live; and he believed the school was the place to learn that lesson.

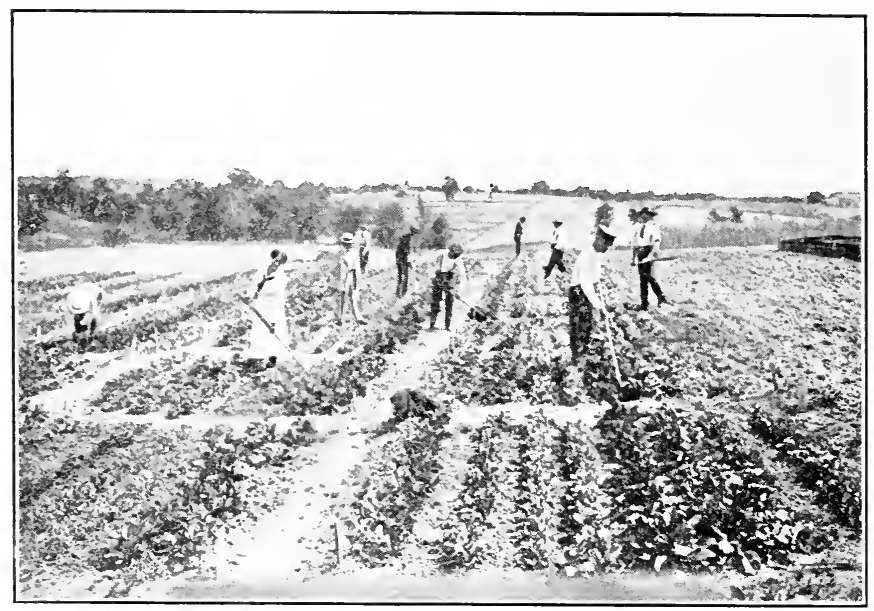

Truck Gardening, Tuskegee Institute

He wanted the children to study practical things; the things they needed. He thought, therefore, that the school ought to be very closely related to life. His idea was that that school was best which turned out students who could earn their own living at once; who had the ability to take care of themselves in whatever environment they happened to be; and who had genuine character. 
"My experience has taught me," he says, "that the surest way to success in education, and in any other line for that matter, is to stick close to the common and familiar things - things that concern the greater part of the people the greater part of the time." 1

It was this belief in the close relation between school and life that caused him to have his students, at the beginning of the building of Tuskegee, cut down the trees, plant the crops, make the bricks, build the buildings, cook the food, care for the dormitories, look after the live stock, and do everything that was to be done about the place. He wanted his students to learn to do well all these tasks that they would face in later life. And he also wanted them to learn that it was a perfectly honorable and dignified and sensible thing to labor, to work, to do anything that was honest and useful.

Perhaps there is no better way of understanding Washington's ideas of education and just what he was striving to do at Tuskegee than to describe the commencement exercises at this school.

"On the platform before the audience is a miniature engine to which steam has been piped, a miniature frame house in course of construction, and a piece of brick wall in process of erection. A young man in jumpers comes on the platform, starts the engine and blows the whistle. Where-

1 "My Larger Education," by Booker T. Washington, p. I39. 
upon young men and women come hurrying from all directions, and each turns to his or her appointed task. A young carpenter completes the little house, a young mason finishes the laying of the brick wall, a young farmer leads forth a cow and milks her in full view of the audience, a sturdy blacksmith shoes a horse, and, after this patient, educative animal has been shod, he is turned over to a representative of the veterinary division to have his teeth filed. At the same time, on the opposite side of the platform one of the girl students is having a dress fitted by one of her classmates, who is a dressmaker. She at length walks proudly from the platform in her completed new gown, while the young dressmaker looks anxiously after to make sure that it 'hangs right behind.' Other girls are doing washing and ironing with the drudgery removed in accordance with advanced Tuskegee methods. Still others are hard at work on hats, mats, and dresses, while boys from the tailoring department sit cross-legged working on suits and uniforms. In the background are arranged the finest specimens which scientific agriculture has produced on the farm and mechanical skill has turned out in the shop. The pumpkin, potatoes, corn, cotton, and other agricultural products predominate, because agriculture is the chief industry at 'Tuskegee, just as it is among the negro people of the South.

"This form of commencement exercise is one of 
Booker Washington's contributions to education which has been widely copied by schools for whites as well as blacks. That it appeals to his own people is eloquently attested by the people themselves, who come in ever-greater numbers as the commencement days recur. At three o'clock in the

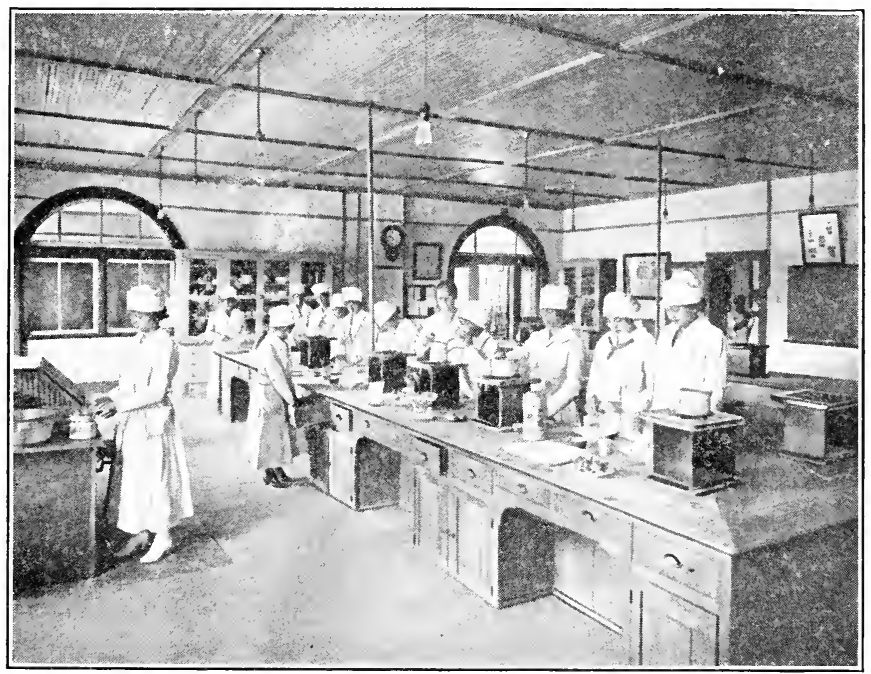

Domestic Science Class at Tuskegee

morning of this great day, vehicles of every description, each loaded to capacity with men, women, and children, begin to roll in, in an unbroken line which sometimes extends along the road for three miles. Some of the teachers at times objected to turning a large area of the Institute grounds into a hitching-post station for 
the horses and mules of this great multitude, but to all such objections Mr. Washington replied, 'This place belongs to the people and not to us.' Less than a third of these eight or nine thousand people are able to crowd into the chapel to see the actual graduation exercises; but all can see the graduation procession as it marches through the grounds to the chapel, and all are shown through the shops and over the farm and through the special agricultural exhibits, and even through the offices, including that of the principal. It is significant of the respect in which people hold the Institute, and in which they held Booker Washington, that in all these years there has never been on these occasions a single instance of drunkenness or disorderiy conduct." 1

"One of our students in his commencement oration last May gave a description of how he planted and raised an acre of cabbages. Piled high upon the platform by his side were some of the largest and finest cabbages I have ever seen. He told how and where he had obtained the seed; he described his method of preparing and enriching the soil, of working the land, and harvesting the crop; and he summed up by giving the cost of the whole operation. In the course of his account of this comparatively simple operation, this student had made use of much that he had learned

1 "Booker T. Washington: Builder of a Civilization," by Scott and Stowe, pp. 57-59. 
in composition, grammar, mathematics, chemistry, and agriculture. He had not merely woven into his narrative all these various elements that I have referred to, but he had given the audience (which was made up largely of colored farmers from the surrounding country) some useful and practical information in regard to a subject which they understood and were interested in. I wish that any one who does not believe it possible to make a subject like cabbages interesting in a commencement oration could have heard the hearty cheers which greeted the speaker when, at the close of his speech, he held up one of the largest cabbages on the platform for the audience to look at and admire. As a matter of fact there is just as much that is interesting, strange, mysterious and wonderful; just as much to be learned that is edifying, broadening, and refining in a cabbage as there is in a page of Latin. There is, however, this distinction; it will make very little difference to the world whether one negro boy, more or less, learns to construe a page of Latin. On the other hand, as soon as one negro boy has been taught to apply thought and study and ideas to the growing of cabbages, he has started a process which, if it goes on and continues, will eventually transform the whole face of things as they exist in the South to-day." 1

It can be readily seen from these two accounts 1 "My Larger Education," by Booker T. Washington, pp. 14I-I43. 
just what kind of education Washington believed in and tried to give his students at Tuskegee. It was quite different from most of the training that had been given the negro after the war. In those early days of freedom, many of the negroes seemed to have the idea that the bigger the book and the harder the words in it, the better the education was that they secured. Some of them thought, too, that they were not educated unless they studied Latin and Greek and higher mathematics, and other similar subjects. Booker Washington did not mean that history, literature, and foreign languages should not be studied and had no value. What he was emphasizing was the fact that boys and girls should first get a clear idea of things about them. Then they would be able better to understand and appreciate such subjects as history and literature.

One other feature of the kind of education that Tuskegee stands for ought to be mentioned, and that is the extension work. 'This work has become a very large part of the Institute. The extension work is not so much a matter of teaching, of education in the usual sense, as it is an effort to give direct and practical help to people outside the college walls. Most of this extension work has been done in Macon and adjoining counties. From the first month of his school, Washington began to go into the country round about and mingle with his people. He went to their homes, 


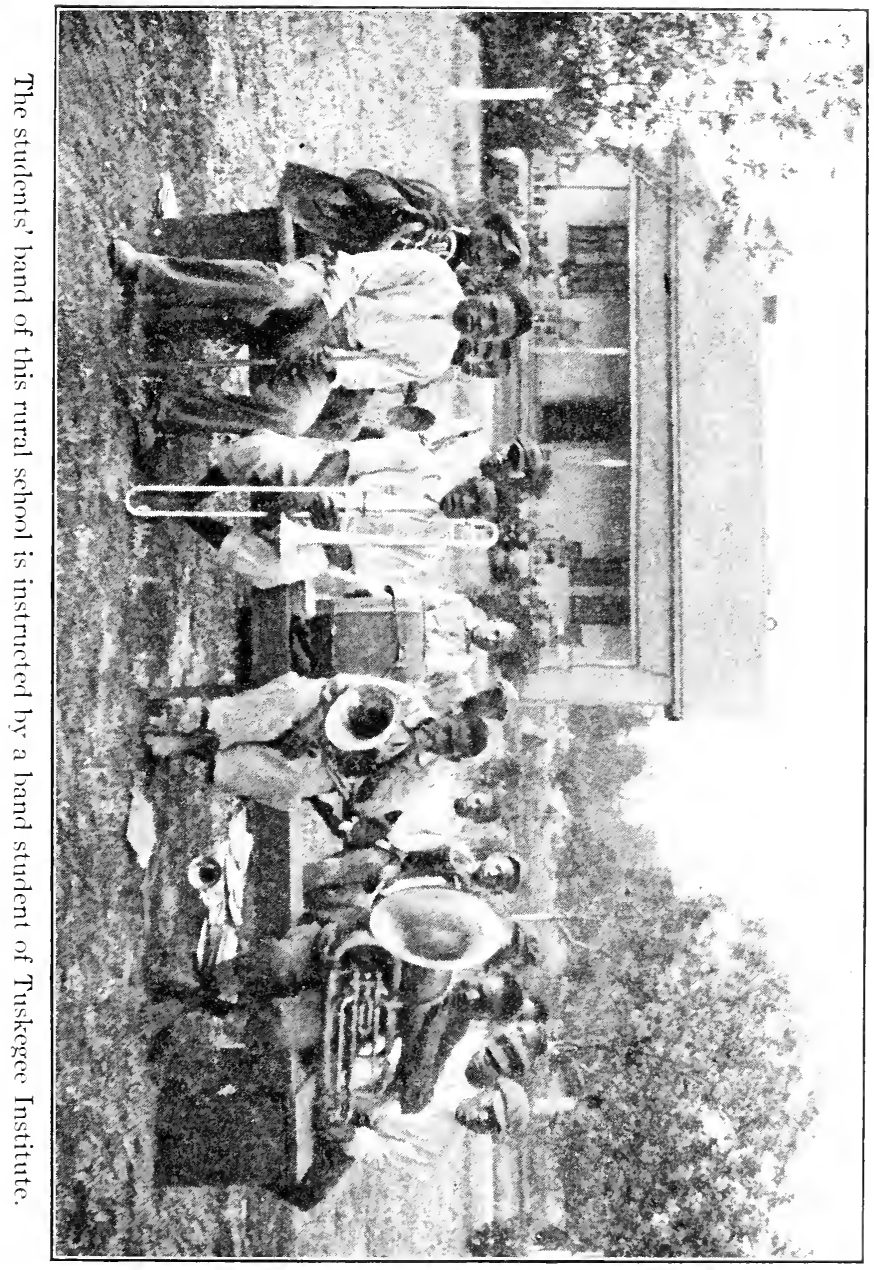


their churches, their schools. He saw their poor farms, their lean stock, their dilapidated houses, their lack of the comforts and necessities of good living. The homes, the churches, the schoolhouses were in bad condition. Washington had the greatest sympathy for these people, knowing why they were in poverty and ignorance, and he had a great desire to help them. And it is through this extension work that these people are helped.

The Institute sends its workers throughout the surrounding country to show the farmers improved farm machinery, better methods of farming, better breeds of live stock of all kinds, better methods of dairying, and better ways of preparing food, keeping house, and caring for the children. They insist on improving the school buildings, the churches, and the homes. As a result of this work, there are now in Macon County a number of neat new schoolhouses, with a teacher's house alongside each school, several acres of land adjoining, and a good church close by. Thus clean, pleasant, and thoroughly happy communities are created. In such communities there is the smallest amount of crime, and there is the largest amount of prosperity and contentment and enjoyment.

All the graduates of Tuskegee are enthusiasts for education and community builders. Wherever they go, they stand for the best in life. They are devoted to Tuskegee and its spirit and its 


\section{EDUCATIONAL LEADER}

ideals. It is this devotion which makes them industrious and capable and law-abiding and helpful in every possible way in the communities in which they live. Hundreds of small schools have been established all over the South by these graduates,

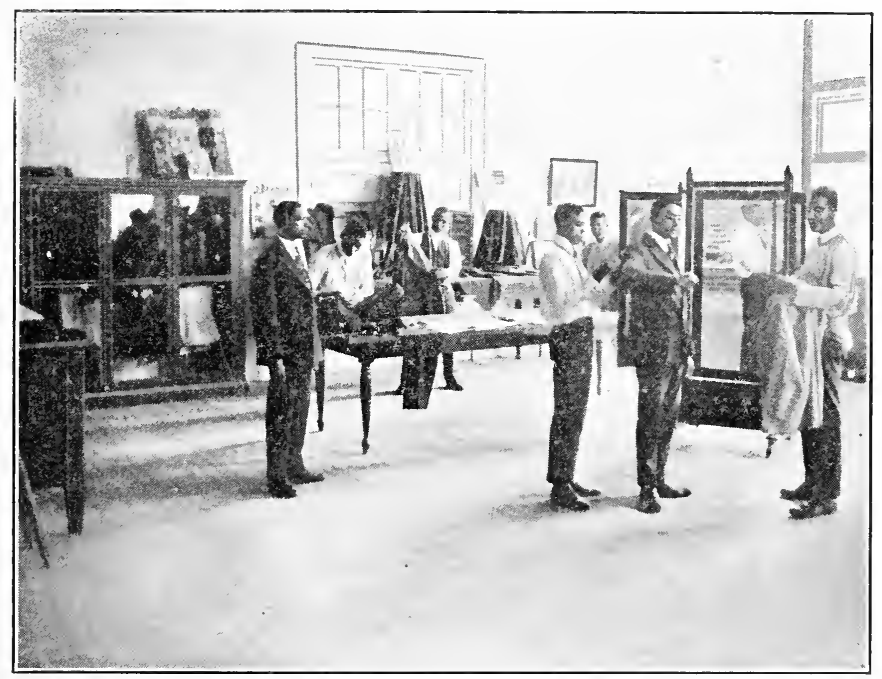

Tailoring Division, Tuskegee Institute

patterned on Tuskegee. It is impossible to overestimate the good they have done.

Tuskegee has grown to be one of the greatest schools in the country, and the greatest of all schools for the negroes. It has grown from IOO acres and three little buildings to a plant of $2 \mathrm{IOO}$ acres and I I buildings. Instead of one teacher with 30 pupils there are now more than 200 teachers 
and 1500 students. The institution has a large endowment, and it owns 20,000 acres of land given it by the United States Government. It keeps a large dairy herd, runs a large farm, a poultry farm, and keeps a large number of pigs, horses and sheep. Every phase of education is taught, but the main work is industrial, - carpentry, brick masonry, basket making, metal working, draughting, automechanics, blacksmithing, telegraphy, farming, dairying, lumbering, building, cooking, sewing, nursing, housekeeping - all these and a large number of other callings are taught. It is through such training as this that Washington believed that the negroes, in largest numbers, would first get their best start in life.

Life is strenuous in this school. Here is an outline of the daily work: "5 A.M., rising bell; 5:50 A.M., warning breakfast bell; 6:00 A.M., breakfast bell; 6:20 A.M., breakfast over; 6:20-6:50 A.M., rooms cleaned; 6:50 A.M., work bell; 7:30 A.M., morning study hour; 8:20 A.M., morning school bell; 8:25 A.M., inspection of young men's dress in ranks; 8:40 A.M., devotional exercises in chapel; 8:55 A.M., 'five minutes with the daily news'; 9:00 A.M., class work begins; I 2 :OO M., class work ends; I $2: 15$ P.M., dinner; I :OO P.M., work bell; I :30 P.M., class work begins; 3:30 P.M., class work ends; 5:30 P.M., bell to 'knock off' work; 6:00 P.M., supper; 7:IO, P.M., evening prayers; $7: 30$ P.M., evening study hour: 8:45 P.M., evening 
Situdy hour closes; 9:20 P.M., warning bell; 9:30 P.M., retiring bell." 1

Washington has done more for the education of the negro than any other one man, white or black. His work at Tuskegee, his great educational campaigns, and his speeches and writings have combined to make his accomplishments of supreme value. Not only has he done this for the negro, but his work has helped the cause of education for the white people very greatly. All education in the South was backward. Like his great teacher, General Armstrong, Washington realized that in their progress the two races were bound together in the South, and that they must grow or step backward together. It is impossible for the negro to make his best progress unless the white man does so at the same time. And of course this works both ways. Because he believed this, Washington was anxious for school conditions for white people to change just as well as the school conditions for negroes. Besides, he wanted all the people to have the advantages of education. He did not hate anybody, and consequently did not want anybody to be deprived of the best there was in life. He did not want anybody, white or black, to fail to have his best opportunity. So he worked for the advancement of the cause of the white schools as well as the black, and his services to the white schools were great.

1 "Up from Slavery," by Booker T. Washington, p. 3 I 4 . 


\section{IO4 BOOKER T. WASHINGTON}

The future of negro education is very bright. Schools and colleges are being built every year. Better teachers are being prepared. Children are going to school in larger numbers than ever before, and their work is more satisfactory.

Every year the states appropriate more and more money for negro education. The negro is now able to pay a large part of the cost of his own education, and he is very willingly doing so.

The negro is determined to get an education. When he gets it, he will be a better citizen. And the better the citizens of a country are, the better life is in every way, and the more completely are all our problems solved. 


\section{CHAPTER XII}

\section{LEADING HIS PEOPLE}

IMMEDIATELY following Washington's great speech in Atlanta in I895, there came the statement from all parts of the country, "Here is the new leader of the negro race." During the last years of slavery, and the Civil War, and on for years after the war, Frederick Douglass, as has been said, was the acknowledged leader of the negro in the United States. Douglass had died in the early part of the year I895. It seemed that this man Washington had been raised up to take his place. The Atlanta speech continued to be a topic of discussion throughout the country, and coupled with this discussion was invariably the statement that here was the new leader of the race.

Washington says that he was at a great loss to know what people meant when they referred to him as the leader of his people. Of course, this leadership was not a thing that he had sought. The people thrust this duty upon him, and of course no man has a right to shun or dodge responsibility that is thus bestowed.

He was not in doubt long as to what it meant to be a leader. One of the first things that hap- 


\section{Io6 BOOKER T. WASHINGTON}

pened was the large number of invitations that came to him to deliver addresses. These requests came from all parts of the country and from all sorts of organizations. A very large number of these invitations he was compelled to refuse. However, when he felt he could serve his institution and his people, he always accepted. He represented the Negro at the unveiling of the monument of R. G. Shaw, in Boston; and at the Peace Convention in Chicago in 1898 , at which time President McKinley spoke. He attended most of the large religious gatherings of his people throughout the country, and spoke before them. Almost immediately there began to pour in on him a perfect flood of letters from all parts of the country, from white and black, high and low, rich and poor, asking a thousand different questions. Now it would be a letter from a railroad president asking about some problem of dealing with his employees; now from a school man asking about the segregation of the races in schools. Again, from a legislator, asking advice on some legislation; but principally the letters came from his own people, asking all sorts of questions about a multitude of things. One man wanted Washington to use his influence to secure the adoption of a flag for the negro race; another wanted his backing for a patent medicine that would take the curl out of the negro's hair. Another wanted to know if the negro race was dying out; another, 
if the race was being blended with the white race; another, if he thought the negro was being treated right politically. Perhaps the most remarkable request, however, was from a woman, who wanted him to find her husband who had deserted her some years before. And in order that he might be easily identified she describes him: "This is the hith of him 5-6 light eyes dark hair unwave shave and a Suprano Voice his age 58 his name Steve." 1

To all of these letters he replied in the fullest and frankest and kindest way.

Whenever there was race friction in the South, he was invariably called upon either to go in person or to send a message. For example, when the Atlanta riots occurred in I906, Washington was in the North. He took the first train South. He went among his own people in Atlanta first, and then he went to the white people - to the Governor, the Mayor, the leading citizens, ministers and merchants. Largely through his wise counsel and efforts order was restored, and plans were made for the future.

As a spokesman for his people he wrote constantly for the press. Such papers as the Montgomery Adiertiser, the Atlanta Constitution, the New Orleans Picayune, the Louisville Courier Journal, the Chicago Inter-Ocean, and the Boston and New York papers gladly published his articles.

1 "Booker T. Washington: Builder of a Civilization," by Scott and Stowe, p. 45 . 


\section{Io8 BOOKER T. WASHINGTON}

He also contributed frequent articles to the weekly journals, such as The Outlook, and to the monthly magazines, such as The Century Magazine.

He carried this phase of his leadership even further than the current press, in that he made some notable contributions to the historical literature of his race. The first book he wrote was "Up from Slavery." This is one of the greatest pieces of literature published in America. The Hon. Walter H. Page, late Ambassador to Great Britain, said: "The only books that I have read a second time or ever cared to read in the whole list (of literature relating to the negro) are 'Uncle Remus,' and 'Up from Slavery,' for these are the great literature of the subject." 1

Believing the accomplishments of the race should be better known to his own people, Washington determined to write a history of the Negro. "The Story of the Negro - the Rise of the Race from Slavery" was the title of the book he wrote, setting forth the wonderful progress of his people.

Other books by him were, "My Larger Education," "Learning with the Hands," - about eleven titles in all. These books are of high literary merit, and in no other way, perhaps, did Washington so definitely place himself as a leader of his people as in the realm of authorship. These books, in addition to their literary value, were of great benefit to the white race as well as to his own race, in

1 "Up from Slavery," by Booker T. Washington, Introduction, p. xx. 
getting before all the people a proper estimate of the real accomplishments of the negro.

One of the most important phases of his leadership of the negro was in the organization of the National Negro Business League. It was one of Washington's strongest beliefs that the negro must prove himself able to exist and prosper in business matters. The race - individually and collectively - must demonstrate its ability to take care of itself in all phases of industrial life. Another of his important principles was that the negro should emphasize his opportunities rather than his drawbacks. As he went about the country, he noted the wonderful progress made by the negro in all lines of business. He felt that it would be a great inspiration to those who had achieved success or leadership to know each other, and a still greater encouragement to all the people if they knew the real progress being made. Acting upon these ideas, he called a meeting of representatives of a large number of businesses to be held in Boston, in August, I900. Here was organized the National Negro Business League. Washington was made president and continued to hold this office until his death in I9I 5 .

The organization brought together from year to year all the representative negro business men of the country. They made reports of their progress and planned for future advancement. The league has been a wonderful factor in the development of 
the business life of the negro. Several other organizations, such as the Negro Press Association, the Negro Bar Association, the Negro Funeral Directors' Association, and others have grown out of this league. It was through this league, as perhaps through no other agency, that the negro learned of his own great wealth, of his success in banking, in manufacturing, in merchandise, in the undertaking business, and in a large number of other industries. It gave him a wonderful pride in the accomplishments of his race. He knew that the negro was proving to the world that he possessed all the elements necessary for handling any phase of his economic life. He could take care of himself in the business world.

Washington did a great deal for the negro farmer. It has already been pointed out how he served the people of his county, and how the extension work of the Institute was used to help the farmer. In addition to this he organized the Tuskegee Negro Conference. In the beginning, this was a sort of agricultural experience meeting on a large scale. The good farmers from all the surrounding country were brought in, and each was asked to relate his successful experience. Every phase of farm life was covered. Every person present was profited by the experience and the success of his neighbor. This conference has greatly broadened in scope and has grown to be of large proportions and great influence. 
Washington was truly the Moses of his people, as Andrew Carnegie had said. He led them with great wisdom in their thought and their conduct. $\mathrm{He}$ was their spokesman, their interpreter. He guided them to higher and better things. He made the white man and the negro know each other better and understand each other better. $\mathrm{He}$ lessened the friction between the races and increased the good will. He brought encouragement and inspiration to his own race and gained the sympathy and coöperation of the white race. Everywhere he opposed ignorance and prejudice and injustice in any form. Because of his wisdom and tact as a leader, not only the negro but the entire nation was helped. 


\section{CHAPTER XIII}

\section{POLITICAL EXPERIENCES}

Most of the negroes who gained any prominence or influence in the years just after the Civil War entered politics. Bruce and Revels had been United States Senators; Elliott and Smalls and a dozen others had been Congressmen; Pinchback, Lynch, Langston, Gibbs, and Greener had been sent for diplomatic service to foreign countries, and others had held high State offices; and a multitude of negroes had been county and city officials of various kinds.

Everybody expected Washington to accept some kind of political position, but he steadfastly refused. Time after time, men of his own race and white men urged him to run for office, or accept an appointment by the President to high office. This he absolutely refused to do. He said that his service, whatever it was worth, would be given, not in politics but in education. He believed that entirely too much emphasis had been placed on holding office by the negro, just after the war. He was more concerned about whether or not his people could have the opportunity to earn an honest living than he was about getting some political job. 


\section{POLITICAL EXPERIENCES}

He was often misunderstood about his ideas on holding office and the whole question of the part the negro should take in politics; for he was convinced that there were other things far more important at that time to the negro than the matter of voting.

There was one phase of politics, however, that Washington did keep in close touch with. This can be best explained by giving some of his correspondence.

"Theodore Roosevelt, immediately after taking the oath of office as President of the United States, in Buffalo, after the death of President McKinley, wrote Mr. Washington the following note:

Dear Mr. Washington:

Buffalo, N. Y.

September I4, I90I.

I write you at once to say that to my deep regret my visit South must now be given up.

When are you coming North? I must see you as soon as possible. I want to talk over the question of possible appointments in the South exactly on the lines of our last conversation together.

I hope my visit to Tuskegee is merely deferred for a short season.

Faithfully yours, (Signed) Theodore Roosevelt.

Booker T. Washington, Esq. Tuskegee, Ala.

" In response ro the above note Mr. Washington went to the White House and discussed with the 


\section{4 BOOKER T. WASHINGTON}

President 'possible future appointments in the South.", 1

Immediately following this conference with the President, there was a vacant judgeship in Alabama which gave the President an opportunity to carry out his ideas about Southern appointments. He called upon Washington for advice, and Washington, being unable to go himself at the time, sent his secretary, Emmett J. Scott, to Washington as his representative. Largely upon the recommendation of Washington, Judge George Jones, a Democrat, was appointed to this position. This was an event of great significance indeed, when a Republican President of the United States appointed a Southern Democrat to office. It was done in accordance with the ideas of both the President and Washington, - that only men of the highest fitness, regardless of color or party, should receive appointment.

From this time on, Washington was one of the President's chief advisers in Southern appointments.

President Roosevelt, of course, appointed many negroes also. He believed that, when negroes possessed the proper qualifications for offices, they should have a share in them. Washington did not try to get very many negroes appointed, but he did try to get the very best negro when one was

1 "Booker T. Washington: Builder of a Civilization," by Scott and Stowe, p. 49 . 
appointed. In other words, he was trying to improve the quality rather than increase the quantity of negro officeholders. After one of Washington's speeches, in which he laid special emphasis on this idea, President Roosevelt sent him the following letter:

My dear Washington:

That is excellent; and you have put epigrammatically just what I am doing - that is, though I have rather reduced the quantity, I have done my best to raise the quality of Negro appointments.

With high regards,

\author{
Sincerely yours, \\ Theodore Roosevelt. ${ }^{1}$
}

Throughout the administrations of President Roosevelt and President Taft, Washington was constantly called into conference and rendered a lasting service to his own race and to the people of the country in giving wise counsel, not only about politics but about a great many things pertaining to the welfare of his people.

Washington was often criticized very severely by members of his own race for his position with reference to voting. His ideas on this question are well stated in the following quotation:

"I am often asked to express myself more freely than I do upon the political condition and the polit.cal future of my race. . . My own

1 "Booker T. Washington: Builder of a Civilization," by Scott and Stowe, p. 56. 


\section{II6 BOOKER T. WASHINGTON}

belief is, although I have never before said so in so many words, that the time will come when the negro in the South will be accorded all the political rights which his ability, character, and material possessions entitle him to. I think, though, that the opportunity to freely exercise such political rights will not come in any large degree through outside or artificial forcing, but will be accorded to the negro by the Southern white people themselves, and that they will protect him in the exercise of these rights. Just as soon as the South gets over the feeling that it is being forced by 'foreigners' or 'aliens' to do something which it does not want to do, I believe that the change in the direction that I have indicated is going to begin." 1

Again he says: "I contend that, in relation to his vote, the negro should more and more consider the interests of the community in which he lives, rather than seek alone to please some one who lives a thousand miles from him and his interests."'2

While he believed, theoretically, in universal, free suffrage, he very frankly admitted that the peculiar conditions existing in the South made it necessary to put restrictions upon the ballot. He was opposed, however, to any discriminations in the law; and he urged with all his power that the negro be given good educa ional and business

1 "Up from Slavery," by Booker T. Washington, p. 234.

${ }^{2}$ Ibid., p. 202. 


\section{POLITICAL EXPERIENCES}

advantages, so that he might fit himself for the full responsibilities and duties of life.

Washington himself never had any trouble about voting. He always registered and always voted, and no one ever raised an objection to his doing so. 


\section{CHAPTER XIV}

\section{VISITS TO EUROPE}

WASHINGTON was a great traveler. He was away from his home at least half of each year and often more than that. He traveled principally in the North, making speeches and interviewing people who might help Tuskegee. While on these trips, he did most of his reading and writing. He was very fond of newspapers and magazines. When he started on a long journey, he surrounded himself with a large number of papers and magazines and books, which he thoroughly enjoyed. History was his favorite field of reading outside of newspapers and magazines. He was especially fond of biography - of reading about real men, men of action and thought and great talents. Much of his greatest inspiration as a boy came from reading the lives of great men. Lincoln was his greatest hero. He said that he had read practically every recorded word of Lincoln's.

Washington also did much of his writing on these trips. He kept his stenographer with him all the time, and, when he was not reading, he was usually dictating a speech, or a letter, or an article for a magazine. A large part of his greatest book, "Up from Slavery," was written while he was on 


\section{VISITS TO EUROPE}

the train or waiting at stations between trains. It is remarkable that he should have been able to accomplish so much under such circumstances, for traveling was hard work. He often had to get up in the middle of the night to catch a train and then ride all day, often without Pullman accommodations. He said that he had slept in three different beds in one night, so broken was his rest and so often did he have to change trains in order to keep engagements. Undoubtedly it was this hard traveling that helped to break down his great strength and wear him out.

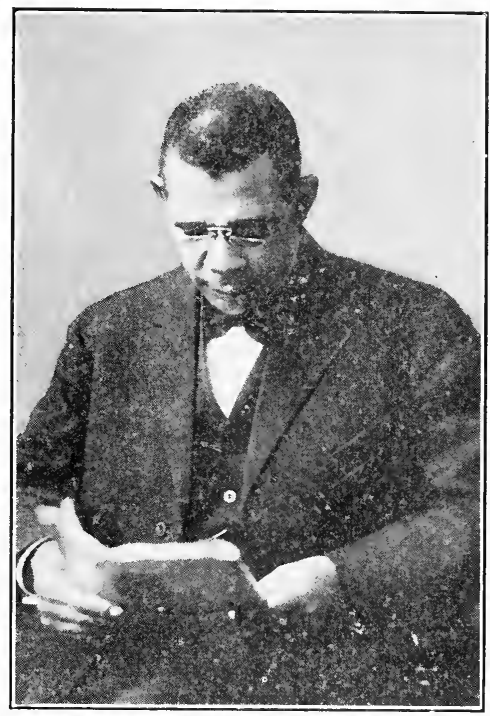

Booker T. Washington, First PrinCipal of Tuskegee Institute

In 1899 he made a speech in Boston, and some of his friends noticed that he scemed extremely tired. He remained in Boston several days. One day during his stay a friend asked him if he had ever been to Europe. He replied that he had not. He was asked very casually whether he thought that he would enjoy a trip to Europe. 


\section{20

He said that he certainly would, but he did not ever expect to have such a pleasure. A day or two later some of his friends came to him and told him they had a little surprise for him, that they had made arrangements for him and his wife to go to Europe in the summer and spend several months on a vacation.

Washington was very greatly surprised. He thanked his friends very cordially for their interest but told them that he could not afford to take the trip. Whereupon they told him that all the money for the expenses of the trip had already been raised, and that it would not cost him a cent. He thanked them again very sincerely but told them he could not think of leaving his work that long, - that money had to be raised for Tuskegee, and that he had to stay right on the job to get it. Then they told him that a group of his friends had already raised enough money to keep Tuskegee going until he got back. He then gave another excuse. He was afraid people would say that he was "stuck up"; that since he had made some success in the world he was trying to show off and play the big man. His friends told him that sensible people would not think such a thing, and that he need not bother about the people who had no sense. Washington thought, too, that he had no right to quit work so long. He had worked all his life. There was a world of work yet he had to do. To go off on a vacation of several months, 
when there was so much to be done, and when other people were at work, seemed wrong to him. But he realized finally that a reasonable amount of rest, when one is tired, means more and better work in the long run.

So it came about that, on May io, I 899, Washington and his wife went aboard the ship Friesland in New York harbor and sailed for Europe. It was a wonderful experience for Washington. In the first place, as he went aboard the ship, he received a message from two of his friends telling him that they had decided to give him the money to build a magnificent new building at Tuskegee. That was a good "send-off." Washington was a bit uneasy about how people would treat him aboard ship. He knew what unfortunate experiences some members of his race had had in times past. But the captain received him cordially, and everybody on board was exceedingly courteous to him and to his wife in every way.

Washington on his way to Europe! It seemed to him like a dream. Again and again he had thought of Europe, - much as he did of heaven, a goodly place, but far away. It had never even occurred to him that he would ever go to Europe. And now he was on his way! He was like a schoolboy; he was happy over the prospect of a wonderful trip.

He did not get seasick on the voyage, as most of the passengers did. The weather was fine, and 
he had a glorious voyage. But he did not know how tired and worn out he was until he relaxed. About the second day he began to sleep, and he says that from then on until they landed he slept at least fifteen hours every day. He continued the habit of long hours devoted to sleep all the time he was gone, and it was one of the means by which he restored his depleted strength.

After a fine voyage of ten days, they landed at Antwerp, a famous old city of Belgium. Here they spent a few quiet days, finding it extremely interesting to observe the people with their dress and manners and customs, different from anything they had ever seen before.

Then they went on a delightful journey through the picturesque country of Holland. Washington, always interested in farming and especially dairy farming, was greatly delighted on this trip. On every hand were the wonderful farms of the Dutch. He had never seen such intensive cultivation of land. Every foot of ground was used. Vegetables were grown in boxes, one row above another, on the back porches of the houses, so precious was the scarce land. Ten or twelve acres was a good big farm. Coming from a country where land is so abundant and cheap and so extravagantly wasted and so carelessly cultivated, these beautiful farms were a delight to him. And the herds of fine Holstein cattle pleased him im- 
mensely. He loved cows; and these seemed to be the finest herds he had ever seen in his life.

Out of Holland and back into the historic and now heroic Belgium, the party went, going to Waterloo, the famous battlefield of Napoleon's defeat, and to other places of interest; and from here to Paris, the gayest and brightest of all the cities of Europe, the capital of France.

While in Paris, Washington met a number of distinguished Americans. He made two or three important speeches and was given a reception by the American ambassador at Paris. He met exPresident Harrison, General Horace Porter, our ambassador, Justices Fuller and Harlan, of the United States Supreme Court, and other distinguished men, all of whom were most cordial and friendly.

The American whom he found most interesting in Paris, however, was a negro - Henry O. Tanner. Tanner is an artist, a painter. $H e$ is the son of the beloved Bishop Tanner and was born in America. He showed marked talent for painting in his youth. When he grew up, he determined to go to the greatest city in the world for art. $\mathrm{He}$ went to Paris and became so successful in his work that he has continued to live there. He has several paintings in the Louvre, the greatest and most exclusive art gallery in the world. A picture cannot be put in the Louvre unless it is recognized and accepted as a great work of art. Washington 
spent much time with Tanner and was greatly pleased to see what marked success had been won by this American negro. He took it as proof of his contention that, when a negro proves himself really worthy, he will be recognized and honored, for Tanner enjoyed the esteem and regard of all his associates, regardless of race. And they esteemed him because of his worth, and not because of his color.

From Paris the Washingtons went to London. Here they visited many places of historic interest, - the British Museum, Westminster Abbey, St. Paul's, and the House of Commons. They met many interesting people, - the Duke and Duchess of Sutherland, Joseph H. Choate, American ambassador to England, Henry M. Stanley, the great African explorer, with whom Washington conversed at length. They were also received by Queen Victoria, at Windsor Castle.

It had been a wonderful trip. Washington had learned many lessons from the Old World. He had seen and talked with men who helped him in the better understanding of his own great task. He had had a wonderfully good time. He was thoroughly rested - a new man. He plunged into his work again upon his return with great vigor and enthusiasm.

Washington made two other trips to Europe during his lifetime. The second one was largely like the first - a trip for recreation and pleasure 
and rest. But the third trip was undertaken with a serious purpose. He wanted to see how the poor people of Europe lived, and how their living conditions compared with those of the workingman in the United States. He was particularly anxious to see how conditions there compared with those affecting the negro population of the South. He also wanted to see whether or not he could find anything in Europe that would justify the system of education he had established at Tuskegee. So this time he left the usual highways of travel and went far into the interior, visiting the peasant in his hut, in the remotest regions of the country, - the miner toiling underground, the laborer in the quarry, and the poor man at his work whatever it was and wherever he could be found. He visited the farms in the remote parts of Poland, Austria, and Italy. He went to the sulphur mines in Campo Franco. At Catania he saw the grape harvest and the men barelegged, treading the wine press as they did in Bible times.

In a very remote part of Poland, away up in the mountains, he stopped at a little thatchedroof cottage. Desiring to see how the place looked on the inside, he knocked at the door. In response a man opened the door, and Washington said something to him in English, thinking, of course, that the man would not understand, but that he would be able to see inside the hut. To his utter astonishment, the man answered him in English. 
Upon further conversation, he found that this man had once lived in Detroit, Michigan.

When he was in the mines at Campo Franco, Sicily, he by chance met a man who had once worked in the mines near Malden, West Virginia, where Washington himself had worked when a boy. The world is not such a big place after all!

As a result of his observations of conditions in Europe, Washington came to the conclusion that the negro in the South is, generally speaking, in far better condition than the peasant of Europe. $\mathrm{He}$ also noted that, wherever conditions were fairly good, where the natives owned the land and had developed reasonably good farming conditions, there was no emigration from that region to America. But where conditions were bad, where farms were not well kept, where the people were not permitted or encouraged to own their own homes, from such sections there was always much emigration to America. In other words, good local conditions, land ownership, good schools, and so on, tended to make the people happy, contented, and desirous of remaining where they were. In this fact he saw a great lesson for his own people. He believed that the South is the home of the negro, that here it is possible for him to do his best. He was, therefore, tremendously anxious for the negroes to learn how to cultivate the soil to the best possible advantage, to buy land, to build schools, to establish churches, and 
in every way to become real citizens of the country where they were.

Washington wrote an interesting book describing all that he saw and learned on this trip. It is called, "The Man Farthest Down." As stated before, he pointed out that there were many, many people "farther down" than the American negro; that compared to most of the people of Europe, he ought to be exceedingly thankful that his condition is as good as it is. Of course he did not mean by this that conditions with the negro were what they ought to be; but that the negro should be thankful for the progress that he has made; that he should take courage, and go forward to better things.

The most interesting experience of this trip to Europe was his visit to the King and Queen of Denmark, at Copenhagen. On his first visit to the palace he was received by the King. Washington was much impressed by the King's cordiality and simplicity, by his knowledge of America, and by his acquaintance even with the work Washington was doing at Tuskegee. At the close of the interview, the King invited him to dine at the palace that night.

Now the invitation of a king is the same as a command, and one is always expected to accept. Of course Washington was delighted to accept this invitation.

Washington spent the rest of the day preceding 
the dinner hour visiting the country people near Copenhagen. He was late getting home, and he was terrified when he realized that he might be late for dinner. To keep the King and Queen waiting would be a terrible offense. He dressed as rapidly as he could. But in his haste, he pulled his necktie to pieces, - the only one he had fit for the occasion! He pinned it together the best he could and put it on; but he says that he was in great distress throughout the dinner lest the tie come to pieces again.

He reached the palace just in time for the dinner. He was taken directly to the King, who led him to where the Queen was standing, and presented him to her. She was very cordial and gracious. She spoke English perfectly; and Washington was again surprised to find that she, too, was thoroughly familiar with affairs in the United States, and that she also knew about Tuskegee.

There was a very distinguished group of people present. The dinner was given in the magnificent Summer Palace, and everything was truly royal in its elegance and splendor. Washington says, "As I ate food for the first time in my life out of gold dishes, I could not but recall the time when as a slave boy I ate my syrup from a tin plate." 1

1 "Booker T. Washington: Builder of a Civilization," by Scott and Stowe, p. 157. 


\section{CHAPTER XV}

\section{BOOKER T. WASHINGTON: THE MAN}

Booker WASHINGTON at home, with his wife and children, his garden, his chickens, his pigs, his horses and cows, is far more interesting than Washington the orator, the writer, the teacher, the traveler, the college principal.

No man ever loved his home more than Washington. He had to be away from it much of the time. He was away at least half of each year. This was a great hardship to him, and just as often as was possible he got away from his exacting duties and returned to Tuskegee to find rest and quiet and comfort and joy with his own family.

He was an ear.y riser, when at home, getting up always at 6 o'clock. His first morning task was to gather the fresh eggs. He was very fond of chickens and always kept a number of them. "I begin my day," he says, "by seeing how many eggs I can find, or how many little chicks there are that are just beginning to creep through the shells. . . . I like to find the new eggs myself, and I am selfish enough to permit no one else to do this. ... ." 1

1 "Booker T. Washington: Builder of a Civilization," by Scott and Stowe, p. 307. 
He was very fond of animals of all kinds, but the pig was his favorite. He always kept a number of the very finest breeds of Berkshires and Poland Chinas. After gathering the fresh eggs, his next job was feeding the pigs. After that came a visit to the cows. He always kept a good garden, too, and a part of the early morning was given to working in it. He had a very peculiar custom or idea about his garden work. He always worked barefooted. He said that there was something in the soil that gave one strength and health and power, - but you had to get it by direct contact with the soil.

After this early morning round of work was done, he mounted his horse for an hour's ride. He usually rode over the college farm and thoroughly inspected it; then to the dairy, and all over the college grounds, to see that everything was going as it should.

After breakfast, he went to his office and gave his attention to the day's mail, which averaged daily about I 25 incoming and 800 outgoing letters. Later in the day he would visit classrooms, inspect the building that was going on, go to the great dining hall at dinner, go to the shops, talk to the students and to the members of the faculty as he met them. Just before supper he would call for his horse again and go off for an hour's ride or for a hunt. Sometimes he would walk rather than ride. While on these walks, he would often run 
for a couple of miles at top speed. After supper, there was usually a meeting of some kind, - a committee or faculty meeting, or conference with a delegation of visitors. Chapel exercises, devotional in character, came at 8:30. And after that, very frequently, there was an inspection of the dormitories.

He had three children, Portia, Booker, and Davidson. One of his greatest pleasures was to take the children for a long walk on Sunday afternoons. They would tramp for miles through the fields and woods, gathering flowers or nuts or berries. They studied the trees, the flowers, and the birds. They waded in the streams, ran footraces, and played games.

Every night after supper he would romp and play with the children. He would roll on the floor, let the children ride on his back, play all sorts of jolly games, or he would tell stories. He was an excellent story-teller, and it was always a treat to hear the wonderful tales he could tell.

Washington was married three times. His first wife, as stated in a previous chapter, was Fannie M. Smith, of Malden, who died in I884, leaving a daughter, Portia. The second marriage was to Olivia Davidson, who had been a teacher at Tuskegee from its beginning. She had been of wonderful assistance to Washington in the early days of Tuskegee. She was the mother of the two boys, Booker, Jr., and Davidson. His third 


\section{I32 BOOKER T. WASHINGTON}

marriage was to Margaret Murray, of Mississippi, a graduate of Fisk University and for several years a teacher at Tuskegee. This marriage occurred in 1892 . Mrs. Washington has had a very useful and distinguished career. No woman of her race has helped her people so much in recent

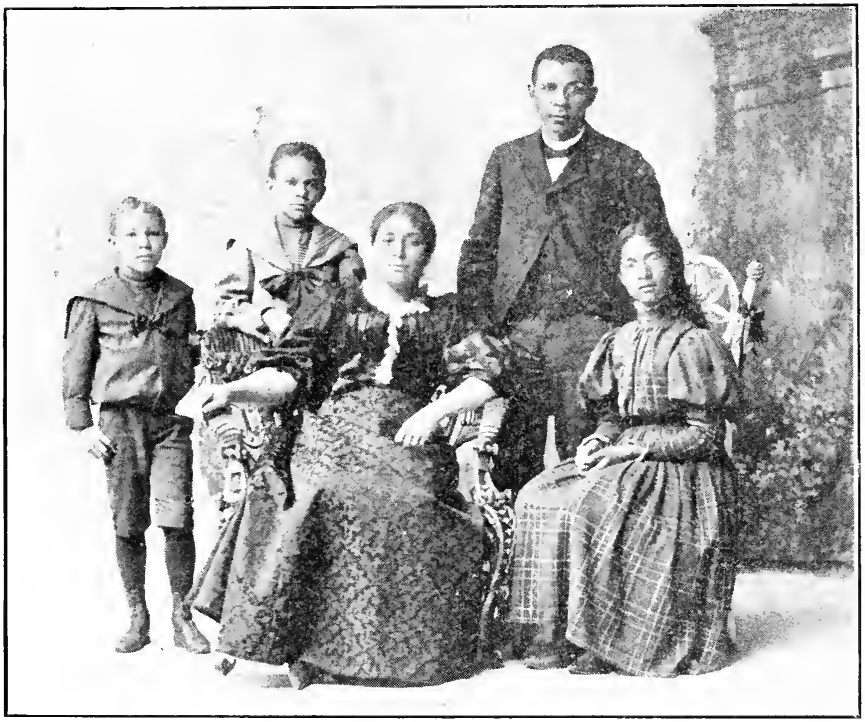

Booker T. Washington and His Family

years. She will be remembered not merely as the wife of Booker Washington, but for her own remarkable service to her people.

Washington was a man of unusual personal appearance. From the description that James Creelman gave of him on the occasion of his famous 
speech in Atlanta, it can readily be seen that he was a man of commanding and striking personality. Wherever he went he attracted attention.

$\mathrm{He}$ was an untiring worker. He went at tremendous speed all the time. He could do as much, as a rule, as three or four ordinary men. He kept a stenographer with him all the time. As he went about the grounds he would dictate suggestions and ideas for changes and improvements. He would often awaken his stenographer at night to dictate a letter or a speech or a statement for the papers. In this way he never overlooked an important thought or idea that occurred to him, and his ideas were always taken down while fresh and vivid in his mind. He often confounded his faculty by his tremendous energy. He would call them in and lay out enough work for them to keep busy for a week and, then, almost before they could get started, demand results. He could work so fast himself and do so much, he never realized that it took other people longer to finish a task.

He had a very active mind. He could think quickly. He was also a good judge of men and knew the worth of a man almost at sight. When any subject was presented to him, he would arrive at conclusions quickly and accurately.

As he grew older, he exhibited a certain amount of absentmindedness, due, perhaps, to concentration of mind. He would meet his best friends on 


\section{I34 BOOKER T. WASHINGTON}

the street and not speak to them. He was so preoccupied by his thinking that he simply did not recognize folks when he met them.

Washington was a proud and independent man. Many people thought he was conceited. He was far too great a man for that. He was not vain and he was not ashamed of himself or his race. He held his head high. He could not be cowed. He had great self-confidence. He knew his abilities and powers and thought it his duty to appraise them properly. This he did in a very intelligent and sensible way. But he was not boastful; in fact, he was very humble. Many of the things which he said and did that were often taken for personal vanity and boastfulness were not personal at all but were evidences of his pride in his race.

Washington had great sympathy for the unortunate. He was constantly bringing up in faculty meeting the case of some poor negro who was in distress, - who couldn't pay the rent, was without food or clothes, or was in hard luck in some way. He insisted that these people be helped regardless of how they came to be in their unfortunate condition. Scarcely a day passed that he did not give aid to some one who needed it.

There was an old, crack-brained preacher who would come to the Institute and speak by the hour right outside the office, but Washington would not let him be disturbed and always gave him a little contribution. 
There was another old negro who had great ability in getting contributions from Washington. "One day, when Washington was driving down the main street of Tuskegee behind a pair of fast and spirited horses, this old man rushed out into the street and stopped him as though he had a matter of the greatest urgency to impart to him. When Mr. Washington had with difficulty reined his horses and asked him what he wanted, the old man said breathlessly, 'I'se got a tirkey for yo' Thanksgivin'!'

"'How much does it weigh?' inquired Mr. Washington.

“' 'Twelve to fifteen poun'.'

"After thanking the old man warmly, Mr. Washington started to drive on, when the old fellow added, 'I jest wants to borrow a dollar for to fatten yo' tirkey for you!'

"With a laugh, Mr. Washington handed the old man a dollar, and drove on. He never could be made to feel that by these spontaneous generosities he was encouraging thriftlessness and mendicancy. He was incorrigible in his unscientific open-handedness with the poor, begging older members of his race." ${ }^{1}$

"Old man Harry Varner was the night watchman of the school in its early days, and a man upon whom Mr. Washington very much depended.

1 "Booker T. Washington: Builder of a Civilization," by Scott and Stowe, p. I44. 


\section{I36 BOOKER T. WASHINGTON}

He lived in a cabin opposite the school grounds. After hearing many ta ${ }^{1} \mathrm{ks}$ about the importance of living in a real house instead of a one or two room cabin, old Uncle Harry finally decided that he must have a real house. Accordingly he came to his employer, told him his feeling in the matter, and laid before him his meagre savings, which he had determined to spend for a real house. Mr. Washington went with him to select the lot and added enough out of his own pocket to the scant savings to enable the old man to buy a cow and a pig and a garden plot as well as the house. From then on, for weeks, he and old Uncle Harry would have long and mysterious conferences over the planning of that little four-room cottage. It is doubtful if Mr. Washington ever devoted more time or thought to p'anning any of the great buildings of the Institute. No potentate was ever half as proud of his palace as Uncle Harry of his four-room cottage, when it was finally finished and painted and stood forth in all its glory to be admired of all men. And Booker Washington was scarcely less proud than Uncle Harry.

"With Uncle Harry Varner, 'Old man' Brannum, the original cook of the school, and Lewis Adams, of the town of Tuskegee, whom Mr. Washington mentions in 'Up from Slavery,' as one of his chief advisers, all unlettered-before-the-war negroes, his relationship was always particularly intimate. These three old men enjoyed the confidence of the white 
people of the town of Tuskegee to an unusual extent and often acted as ambassadors of good will between the head of the school and his white neighbors, when from time to time the latter showed a disposition to look askance at the rapidly growing institution on the hill beyond the town.

“Another intimate friend of Mr. Washington's was Charles L. Diggs, known affectionately on the school grounds as 'Old man' Diggs. The old man had been body servant to a Union officer in the Civil War, and after the war had been carried to Boston, where he became the butler in a fashionable Back Bay family When Mr. Washington first visited Boston, as an humble and obscure young negro school-teacher, pleading for his struggling school, he met Diggs, and Diggs succeeded in interesting his employers in the sincere and earnest young teacher. When, years afterward, the Institute had grown to the dignity of needing stewards, Mr. Washington employed his old friend as steward of the Teachers' Home. In all the years thereafter hardly a day passed when Mr. Washington was at the school without having some kind of powwow with ' $\mathrm{O}$ 'd man' Diggs regarding some matter affecting the interests of the school.

"To the despair of his family Booker Washington seemed to go out of his way to find forlorn old people whom he could befriend. He sent provisions weekly to an humble old black couple from whom he had bought a tract of land for the school. 


\section{I38 BOOKER T. WASHINGTON}

He did the same for old Aunt Harriet and her deaf, dumb, and lame son, except that to them he provided fuel as well. On any particularly cold day, he would send one or more students over to Aunt Harriet's to find out if she and her poor helpless son were comfortable. Also every Sunday afternoon, to the joy of this pathetic couple, a particularly appetizing Sunday dinner unfailingly made its appearance. And these were only a few of the pensioners and semipensioners whom Booker Washington accumulated as he went about his kindly way." 1

Washington had the capacity of making friends. He had the gift of friendship. His white friends were as numerous and staunch as were those of his own race. His close friendship with such men as William H. Baldwin, Jr., H. H. Rogers, and others has already been mentioned. It would be unfair to him and to them to leave the impression that their relations were merely those of benefactor and beggar. They were friends as man to man. Washington and Roosevelt were friends in the same way.

It would be unfairer still to leave the impression that Washington's friends were rich men only and men in the North only. This was not the case. Perhaps his strongest friends were in the South, many of whom were not in the public eye. $\mathrm{He}$

1 "Booker T. Washington: Builder of a Civilization," by Scott and Stowe, pp. I 45 -I 47. 
himself records the fact that few men in his entire career were of such genuine help to him as Captain Howard, conductor on the W. \& A. Railroad. He did not have an enemy in his own town of Tuskegee. All through the South were men whom Washington counted among his warmest personal friends.

Among his own people, he was no less fortunate in his friendships. $\mathrm{He}$ knew and loved Moton and Scott and Banks and Carver and Fortune and Scarborough, and a great host of others. All these were his most loyal and devoted friends. But none of these were really

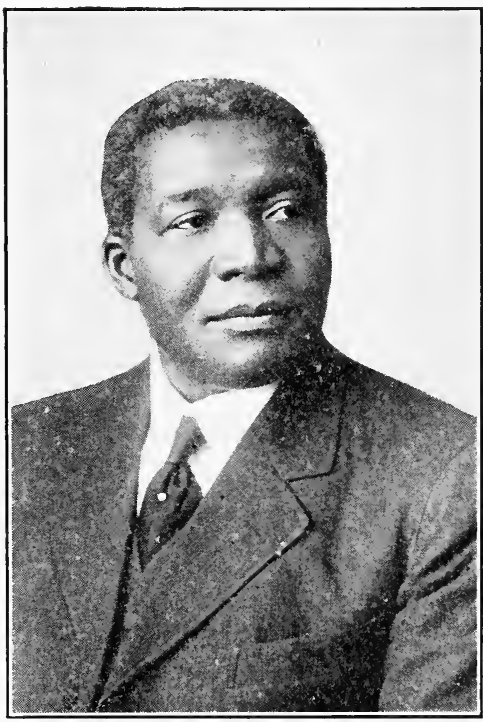

Robert Russa Moton, Successor to Booker T. Washington at Tuskegee any closer to him than "Old man" Diggs or Rufus Herron or many a lowly man of Macon County. There was such sincerity, such a genuineness about this man that all true men were drawn to him.

Washington had a keen sense of humor. This is the reason he was always so even-tempered. He 


\section{I40 BOOKER T. WASHINGTON}

kept perfect control of himself at all times, and it was largely his sense of humor that enabled him to do so. He saw the ridiculous side of things. He could tell perfectly side-splitting stories, particularly about his own people. These stories were always clean and without a sting, and always had some point to them. He was thoroughly goodnatured, and every one in his presence felt refreshed and happy by reason of having come in contact with him.

He had a strong sense of justice. He believed the problems of the white race as well as those of the black race must be settled on a basis of justice, if they were ever to be settled right. The fact that he constantly spoke of justice and fair dealing toward the white race showed that there was no color boundary to this great attribute of his character. He was not quarrelsome; he did not hate; he did not lose his temper when he saw injustice being done to his people However, he never did condone such injustice; he was ever ready to denounce it. He labored unceasingly to bring about a mutual understanding between the two races and to inspire in his own race those principles which he saw with such clear vision. He said that the negro ought to put more time on improving his opportunities than crying over his disadvantages. He believed that the first and most important thing was for the negro to become well prepared for the ballot, and by and by he would 
get it. He argued that the negroes should work and save and study and conduct themselves in the proper way, and that in course of time recognition would come to them. Sooner or later, the right, the just thing, would prevail, and the important thing for the negro was to know he was right.

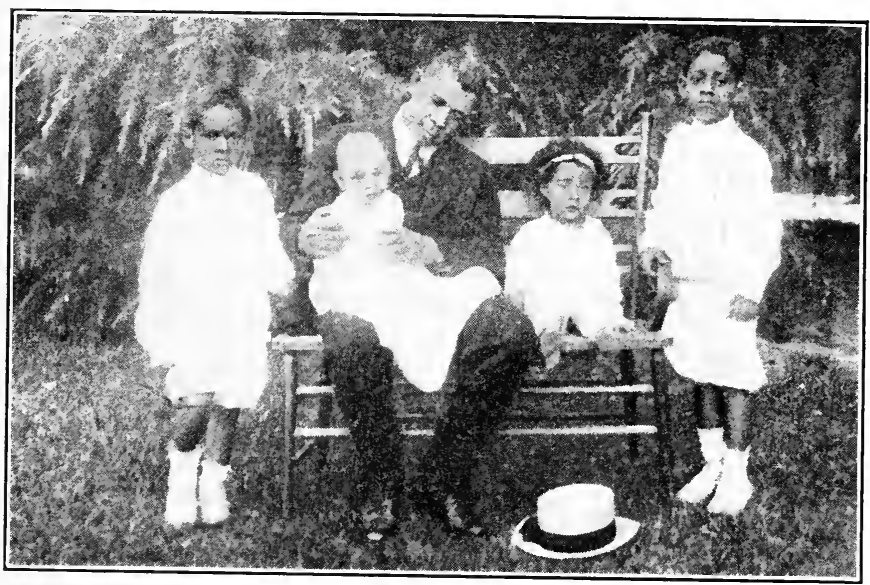

Booker T. Washington and His Grandchildren

Washington had the courage to denounce those members of his own race, particularly some of the ministers, who did not live as they should. This was a bold thing to do and brought much criticism upon him, but, in the long run, it was a great service to his race and to the whole country.

In spite of the fact that Washington was a man of unusual health and strength, his hard work and the great responsibilities he carried began 
finally to tell on him. But he kept on. He had wonderful will power, and he would drive himself to his work from day to day, when other men would have taken to their beds. He could not admit to himself that he was losing strength. Right up to the last, he did an enormous amount of work.

In the early fall of 19I5, he went North to deliver an address before the National Council of Congregational Churches, held in New Haven, Connecticut. Although he had not been entirely well for some time, no one had any idea that he was seriously ill. Shortly after the address in New Haven, he collapsed. His friends in New York City had him removed to St. Luke's Hospital there.

The physicians made a careful examination and frankly told him that he was critically ill and could live but a few hours. When he learned that he must die, he insisted on starting for home at once. The doctors told him that he could not go; that it would mean certain death; that he could not live through the journey. His reply was: "I was born in the South, I have lived and labored in the South, and I expect to die and be buried in the South."

Arrangements were hurriedly made for the journey to Tuskegee. No one believed that he would reach there alive. One of the doctors had said that it was "uncanny to see a man up and 
about who ought, by all the laws of nature, to be dead." When they reached the railway station in New York a rolling chair had been provided for Washington, but he refused to use it and walked to the train leaning on the arms of his friends.

As the train pulled out and headed for his beloved Southland, his spirits began to revive, and he seemed much stronger. He was determined to beat death in this race. As they journeyed on, he would ask the names of the stations. When he was told that they were passing Greensboro, a triumphant look came into his eyes. Charlotte, Greenville, Atlanta - he was winning! Finally they came to Chehaw, the little station five miles from Tuskegee, the junction point of the railroad from Tuskegee to the main line.

A few more minutes, and he saw the familiar and much loved scenes of his own Tuskegee.

He had won!

But his victory was a short one. For when the sun came up on the next morning, the fourteenth day of November, I9I5, Booker Washington was dead. 



\section{INDEX}

Alabama Hall, 69-7o.

Alabama Legislature, 45, 75 .

Armstrong, Gen. S. C., accompanies Washington on tour, 70; founder of Hampton, 23-24; invites Washington as commencement speaker, 32, 77; sends Washington to Tuskegee, 45; sketch of, 22.

Atlanta Constitution, 8I.

Atlanta Speech, 79-8I.

Baldwin, Williain H. Jr., President of Board of Trustees, Tuskegee Institute, 73, 138.

Belgium, Washington's visit to, I 22.

Books, written by Washington, 108.

Buildings, first at Tuskegee, 505 I, 58.

Bulloch, Gov., of Ga., 8I.

Business League, National Negro, I09.

Cabbages, an oration on, 96.

Cabin, description of a, 3 .

Capital, campaign for removal, W. Va., 37.

Carnegie, Andrew, 71, 73, 111.

Carney, Sergeant William H., 85.

Chicago Peace Convention, 106.

"Chopping bee," 52.

Coal mine, 12-13.

Coat, sale of, 28.

Commencement exercises at Tuskegee, 93-95.

Copenhagen, Washington's visit to, 127 .

Corner stone, first building at Tuskegee, 59-60.

Cotton States Exposition, 78.

Creelman, James, 79.
Davidson, Olivia, 49, 66.

Denmark, Washington's visit to, 127.

Douglass, Frederick, 76, 82, I05.

Education of negro, effect of, 909I ; future of, Io.4; negro education after Civil War, 22; Washington's idea of, 9I-93, 98, I03.

Eliot, President C. W., 67.

"Emancipation Proclamation," 8.

"Entitles," 9.

Europe, Washington's trips to, I19-I 28.

Extension work of Tuskegee, Ioo.

Farm, purchase of, 50-5I.

"Festivals," 54.

Freedmen's Bureau, 90.

Gifts to Tuskegee, $54,74-75$.

Hales' Ford, Washington's birthplace, 3 .

Hampton Institute, I5, I7, 20, $22-23,26-27,29-30,32,34$.

Harvard University, 82.

Holland, Washington's visit to, I22.

Howard, Captain, conductor on the W. and A. R. R., I39.

Howell, Clark, editor of Atlanta Constitution, $8 \mathrm{I}$.

Huntington, Collis P., $7 \mathrm{I}$.

Indians, at Hampton Institute, $4 I-42$.

Jamestown, $\mathbf{I}-\mathbf{2}$.

Jones, Judge George, I I 4 .

"Learning with the Hands," Io8.

"Library," Washing ton's first, I 7 . 
Library, Carnegie, 72.

Lincoln, President, 7, I 8.

London, Washington's visit to, I 24.

Mackie, Mary F., 24, 77.

McKinley, President, I06, I I3.

Macon County, Ala., 46, 48, 90.

Madison, Wis., speech at, 77 .

Malden, W. Va., 9-IO, I2, I4, I 7, 29, 34, 37, 126.

“Man Farthest Down," I27.

Marriages, Washington's, 65, I3 I132.

Master of Arts degree, 82.

Morgan, S. Griffitts, 28.

Mother, Washington's, 3, 10, 30.

Moton, R. R., successor to Washington, $\mathrm{I} 39$.

Murray, Margaret, I32.

“My Larger Education,” Io8.

Name, Washington's change of, 9.

National Council of Congregational Churches, $I_{42}$.

Negro, I 5, I8, 22, 37, +I, 56, 59$60,77-78,80,82,85$, I06, I08I I0, I26.

Negro Bar Association, i Io.

Negro Business League, National, I09.

Negro Funeral Directors' Association, i io.

Negro Press Association, I Io.

New Haven, Conn., I 42.

Newspapers, contributions to, I07.

Night school, $35,43$.

Paris, Washington's visit to, I23.

Peabody Fund, 75 .

"Plucky Class," 43.

Politics, Washington's interest in, 38.

Porter Hall, 62, 68.

"Quarters," 3.

Rogers, H. H., 71, 91, I38.

Roosevelt, President, I I3-I I5.

Rosenwald, Julius, 74 .

Ruffner, General Lewis, I6.

Ruffner, Mrs., I6-I7.
School, first, taught by Washington, 34 .

Scott, Emmett J., I I 4.

Shaw, Robert Gould, 85.

Slater Fund, 75.

Smith, Fannie M., 65.

South, condition of, after the

Civil War, 22.

Stanley, Sir Henry M., I24.

Story-teller, Washington as a, $84-85$.

Students, first, at Tuskegee, 4950.

Students' work at Tuskegee, 6I.

Taft, President, II 5.

Tanner, Henry O., I23.

Tuskegee, town of, 46 , I 43 .

Tuskegee Institute: beginnings of, 46-47; Carnegie Library at, 72; character of students of, 4950 ; commencement exercises of, 93-94; extension work of, I00; first buildings of, $50-5 \mathrm{I}$; first year of, 54-55; growth of, IOI; laying corner stone of, 59-6o; negro conferences at, I IO; opening of, 49 .

“Up from Slavery," ro8.

Vessel, unloading, in Richmond, I9.

Virginia, I, I 4 .

Washington, Booker T., Atlanta speech, 78-82; birth, 3 ; books by, I08; character of, vii-viii, I34; children of, I 3 I ; coal mine experiences, I2; commencement speaker, 32; contributor to press, I08; death of, I43; early life of, $4^{-6}$; education, his ideas of, $60-61,9 \mathrm{I}-93,98, \quad$ I03; "examination" at Hampton, 25; founds Tuskegee, 46-5I ; home life, I29-I34; hotel waiter, employed as, 34 ; janitor, works as, 26-27, 20; journey to Hampton, I $7-18$; last illness of, 142; leader of race, 82, I05; league, organizer of, I09; life at 


\section{INDEX}

Hampton, 27-30; marriages of, 65, I3I-I 32; Master of Arts degree, 82; names himself, I II2; orator, makes a reputation as, $70,76,82-86$; personal appearance, 80 ; politics, takes an interest in, I I 2, I I 5-I I6; raising money, 67; service, his ideas of, 88-89; Shaw Monument speech, 85 ; story-teller, as a, $84-85$; teacher at Hampton, 40, 4+; teacher at Malden, 34; trips to Europe, II9-I28; vacations, while a student, 29-30.

Washington, Booker T. Jr., I3 I.

Washington, Davidson, I3I.

Washington, John, 5, 35 .

Washington, Portia, 66.

Wayland Seminary, 36 .

Wheeling, West Virginia, 37. • 




